\title{
An overview of wind energy development and policy initiatives in India
}

\author{
Abhishek Kumar $^{1}\left[\right.$ ] Divyanshi Pal ${ }^{1}$. Sanjay Kumar Kar ${ }^{1} \cdot$ Saroj Kumar Mishra ${ }^{1} \cdot$ Rohit Bansal $^{1}$
}

Received: 19 July 2021 / Accepted: 28 November 2021 / Published online: 15 January 2022

(c) The Author(s), under exclusive licence to Springer-Verlag GmbH Germany, part of Springer Nature 2021

\begin{abstract}
The Indian renewable energy sector has grown at a compounded annual growth rate of $15.51 \%$ in the last five years, where wind growth is about $8 \%$. The Indian government has been adopting changes to create a safe, cheap, and sustainable energy system to fuel vigorous economic growth. The government has made significant efforts in ensuring universal access to energy, giving power to its residents. It is implementing a large-scale deployment of renewable energy, particularly solar and wind. This paper examines the country's wind sector in-depth, including the government policy, financial incentives, and accomplishments. The study goes on to discuss the prospects and problems of the wind sector, as well as solutions to overcome them to reach the estimated target of $140-150 \mathrm{GW}$ by 2030 . Wind power growth in the country has weakened in the last few years which may hamper the country's ambitious renewable energy targets. Wind industry is facing several hindrances ranging from discontinuation of incentives, land acquisition, DISCOM's poor health, change in bidding scheme, old wind sites, etc. Certain steps, such as repowering outdated wind farms, giving generation-based incentives, tax concessions, reassessing the country's wind potential, and constructing competitive renewable energy zones could aid in reviving the wind energy sector.
\end{abstract}

Graphical abstract

WIND DEVELOPMENT IN INDIA

Potential $302 \mathrm{GW}(100 \mathrm{~m})$ $695 \mathrm{GW}(120 \mathrm{~m})$

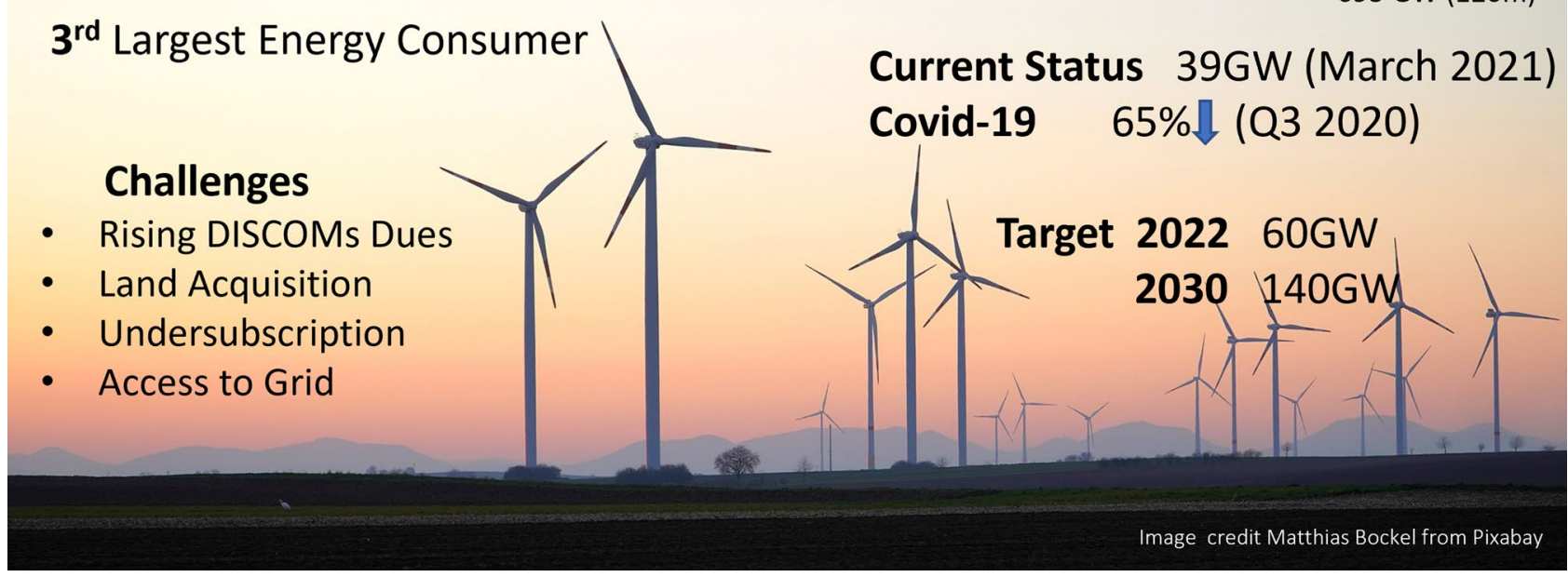

Keywords Renewable energy $\cdot$ Wind energy $\cdot$ Wind policies $\cdot$ Financial incentives $\cdot$ India

Extended author information available on the last page of the article 


\section{Introduction}

Countries across the globe are working tirelessly to provide their entire population with access to electricity. From $72.65 \%$ in 1998 , access to electricity has reached approximately $90 \%$ of the world population in 2018 (The World Bank 2019). Energy usage is growing worldwide, especially in India. The country has become the world's thirdlargest energy consumer; energy use has almost doubled since 2000 , with $80 \%$ of demand still fulfilled by conventional sources of energy (IEA 2021). The global economy, which is built on fossil fuels and growing greenhouse gas emissions, is causing major changes in the climate system (Chaturvedi and Sharma 2020). Climatic changes caused by global warming have been recognized as one of the most serious threats to humanity's existence (Bórawski et al. 2020). This has a noticeable impact on each continent; however, there has been a recent drive to encourage alternative energy sources, with renewable energy accounting for more than $28 \%$ of worldwide power output in 2020 (Kaur et al. 2020). The rise in renewables was primarily at the detriment of coal and gas; still, these two sources account for about $60 \%$ of the world's energy supply (IEA 2020a). The world is seeking green alternatives (Lakhanpal 2019), and for long-term economic and environmental stability, there is a need to promote sustainable power (Rani et al. 2020).

India's electricity industry is one of the world's most diverse. The energy sources used to generate electricity range from traditional sources such as coal, lignite, natural gas, oil, hydro, and nuclear to feasible non-traditional sources such as wind and solar. Power demand in the country has risen quickly in recent years and is anticipated to continue to do so in the coming years. The Indian power sector is heavily reliant on thermal energy, which accounts for around $61 \%$ of the total market share. However, between March 2016 and March 2021, the share of thermal energy decreased by roughly $8 \%$ (Table 1 ). Renewable energy sources (RES) have grown at a compounded annual growth rate (CAGR) of $15.51 \%$ over the previous five years. Wind energy, one of the primary contributors to the country's renewable energy portfolio, accounts for around $10 \%$ of the market. However, its CAGR is just about $7.95 \%$ which is less than that of other renewable energy sources.

The Government of India (GOI) is aggressively encouraging alternative energy sources (Singh 2018), and through its policy actions (Thapar and Sharma 2020), it has been able to establish a favorable climate for investments in renewable energy sources (Ramesh and Saini 2020). Among the renewable sources of energy, wind power has been widely used to satisfy the increasing need for affordable and clean energy (Deep et al. 2020) and it contributes to the sustainable growth of the country (Sadorsky 2021). The Ministry of New and Renewable Energy (MNRE), India, has been instrumental in providing adequate policy support and a conducive regulatory environment to ensure the sector's rapid and orderly development (Khan and Khan 2013). The country has taken several steps to encourage wind energy, including the introduction of Generation-Based Incentives (GBI), Accelerated Depreciation (AD), Renewable Purchase Obligation (RPO), reform of the Electricity Act 2003 and tariff rules, competitive bidding, and the implementation of an offshore wind energy policy in 2018. These policies had multi-level impacts on the development and growth of wind energy in India.

India currently has a cumulative installed wind capacity of approximately $39 \mathrm{GW}$ by March 2021 (Table 1). However, the cumulative capacity addition on a year-overyear basis indicates slow growth. Several studies have been conducted comprehensively in the past on the status of wind energy in India (Thapar et al. 2018; Chaurasiya et al. 2019), policy initiatives and supporting acts (Irfan et al. 2019; Kumar et al. 2019), state-specific wind developments in India (Prakash 2018). However, the declining wind growth creates a reason to conduct an in-depth review of India's wind market. Thus, this paper attempts to
Table 1 Power breakup (Installed capacity in MW)

\begin{tabular}{llllllll}
\hline Year & Thermal & Nuclear & Hydro & RES & Total & Wind & $\begin{array}{l}\text { Wind } \\
\text { power } \\
\text { share (\%) }\end{array}$ \\
\hline March 2016 & $210,675.04$ & 5780 & $42,783.42$ & $45,924.04$ & $305,162.5$ & $26,777.4$ & 8.77 \\
March 2017 & $218,329.88$ & 6780 & $44,478.82$ & $57,244.23$ & $326,832.93$ & $32,279.77$ & 9.87 \\
March 2018 & $222,906.59$ & 6780 & $45,293.42$ & $69,022.39$ & $344,002.4$ & 34,046 & 9.89 \\
March 2019 & $226,279.34$ & 6780 & $45,399.22$ & $77,641.63$ & $356,100.19$ & $35,625.97$ & 10 \\
March 2020 & $230,599.57$ & 6780 & $45,699.22$ & $87,027.68$ & $370,106.47$ & $37,693.75$ & 10.18 \\
March 2021 & $234,728.22$ & 6780 & $46,209.22$ & $94,433.78$ & $382,151.22$ & $39,247.05$ & 10.27 \\
CAGR (\%) & $\mathbf{2 . 1 9}$ & $\mathbf{3 . 2 4}$ & $\mathbf{1 . 5 5}$ & $\mathbf{1 5 . 5 1}$ & $\mathbf{4 . 6}$ & $\mathbf{7 . 9 5}$ & \\
\hline
\end{tabular}

Source: CEA 
provide critical analysis of India's wind development and policy measures, as well as a quick overview of worldwide wind market trends. Additionally, the authors investigate the reasons behind the slow pace of growth and discuss the obstacles, bottlenecks, and legislative hurdles to wind industry expansion in India. We present a thorough study of the enabling environment created by the major states' wind policies.

\section{Data and methodology}

This study is divided into two sections. First, we began by doing a conceptual examination of the concept of wind energy, focusing mostly on the last ten years of academic literature (2010-21) and that expressly utilized the term, 'Wind Energy'. Several peer-reviewed articles were included, demonstrating an expanding corpus of scientific work in the renewable energy field. Popular database Scopus has been used to conduct online searches for the terms "wind energy", "wind energy in India", "wind development in India" and "wind policies." The search yielded over a thousand results at first, but after applying filters such as articles published in journals, focusing on India and subject areas such as energy, environmental sciences, social sciences, and business management, the result was narrowed down to approximately 450 research articles. Given a large number of articles under consideration, we began by reading the titles and abstracts of all publications to identify those that were relevant. After eliminating duplicate entries and those that were irrelevant to our research, the procedure generated around 40 notable peer-reviewed papers.

Secondly, we looked at various articles and identified the gaps or backlogs that existed in the study or where the policies were lacking, and what modification could be done to rectify the situation or challenges. A few recent papers made it clear that the review needed to be broadened to include non-academic literature so that it could provide a clear picture (Prakash 2018; Chaurasiya et al. 2019; Dawn et al. 2019; Sharma and Sinha 2019). The authors also looked at various official policy documents, state-specific wind/renewable policies and guidelines, white papers, green papers, public reports, and research done by national and international organizations. The data were gathered from several publicly accessible government-owned websites/ platforms such as Central Electricity Authority (CEA), Payment Ratification And Analysis in Power Procurement for bringing Transparency in Invoicing of Generators (PRAAPTI), MNRE, Indian Renewable Energy Development Agency Limited (IREDA), and non-government national and international organizations such as International Energy Agency (IEA), Global Wind Energy Council (GWEC), Indian Wind Energy Association (INWEA), and others.

\section{Global scenario}

Wind power is one of the rapidly expanding renewable energy sources with a $93 \mathrm{GW}$ capacity addition in 2020 (REN 2021), which is $36 \%$ of total renewable capacity addition in 2020. During 2010-2020, a total of 545 GW of wind power was added globally, with an average of 55 GW annually. GWEC estimates global annual wind capacity addition of $160 \mathrm{GW}$ and $280 \mathrm{GW}$ by 2025 and 2030 respectively (GWEC 2021a). Global usage is increasing, owing in part to lower costs. The availability of electricity from wind-generated energy has increased significantly. Wind capacity additions are predicted to expand considerably in 2021, owing to the continuous completion of postponed projects in Europe, as well as enhanced development in India and Latin America. The IEA prediction for 2022 predicts a slowdown in worldwide deployment due to changes in support policies, which will be countered only somewhat by rising expansion in Europe. The average costs for generated electricity from onshore wind continue to decrease as the technology matures along with the falling cost of equipment and components. The Levelized Cost of Electricity (LCOE) of onshore wind fell by $48 \%$ from $\$ 0.089 / \mathrm{kWh}$ in 2010 to $\$ 0.039 / \mathrm{kWh}$ in 2020 (REN 2021). Similarly, the LCOE of offshore wind declined by $54 \%$ from $\$ 0.162 / \mathrm{kWh}$ in 2010 to $\$ 0.084 / \mathrm{kWh}$ in 2020 . We expect wind tariff to decline by $15 \%$ by 2025 in line with the renewable tariff estimation of IEA (IEA 2020b). During 2010-2020, onshore wind bettered grid parity tariff, and offshore entered the grid parity zone (REN 2021). However, it continues to face challenges in terms of permitting, regulatory requirements, and public acceptance. Wind energy projects frequently face public resistance owing to the noise they generate; this is referred to as the NIMBY (Not in my backyard) notion (Irfan et al. 2019). Faster wind capacity growth is conceivable with higher objectives and a strong policy framework. Adoption of competitive auctions and removal of regulatory permission processes facilitates the quick addition of wind capacity in numerous regions of the world, including Europe, the USA, and India. Expansion of tax incentives, implementation of renewable purchase obligations (RPOs) and offshore wind auctions and procurements in India, and faster expansion of corporate renewable power purchase agreements (PPAs) facilitate more wind installations. 


\section{Wind power potential in India}

\section{Onshore wind}

The National Institute of Wind Energy (NIWE) predicts a wind energy potential of $695 \mathrm{GW}$ at $120 \mathrm{~m}$ above ground level and $302 \mathrm{GW}$ at $100 \mathrm{~m}$ above ground level as per the survey conducted in April 2010, with Gujarat having the highest potential (Fig. 1). More than $90 \%$ potential exists in seven states with frequent windy weather. However, several independent studies like (Berkeley Lab 2012) claim India's wind potential to be 20-30 times more than the current official estimate. One more study submitted to MNRE in 2015 estimates the country's wind potential to be $2161 \mathrm{GW}-2759 \mathrm{GW}$ at $100 \mathrm{~m}$ and $2540-2959 \mathrm{GW}$ at $120 \mathrm{~m}$ (CSTEP; et al. 2015). These estimates are way more than the government official estimates. This creates a need on the government's part to conduct a new study with advanced techniques to reassess the potential. The government has set a target to achieve $175 \mathrm{GW}$ renewable electricity by 2022 (PIB 2020a), wind shall contribute 60 GW (Boopathi et al. 2021), i.e., 34\% of the total target. The ambitious target has acted as a catalyst of new developments in the wind sector and would help to capitalize on the estimated potential.

\section{Offshore wind}

Initial assessment by NIWE within the identified zones suggests $36 \mathrm{GW}$ of offshore wind energy potential exists off the coast of Gujarat only. Further, nearly $35 \mathrm{GW}$ of offshore wind energy potential exists off the Tamil Nadu coast. However, the country has not started any offshore wind projects.

\section{Current status of wind power in India}

India has been the fourth largest wind energy generator. The country has a cumulative installed capacity of $39 \mathrm{GW}$ approximately till March 2021 (Table 2). Wind Energy has spread across the South, West, and North regions. As of March 2021, the country's total installed capacity was 382 GW (CEA 2021), out of which $24.71 \%$ is contributed by renewable energy, i.e., $94 \mathrm{GW}$ (excluding hydropower). Wind power contributes about $41 \%$ of total installed renewable capacity. As part of the Paris climate change agreement, India stated that by the year 2030, $40 \%$ of the country's electric power will be generated from clean sources (Bandyopadhyay 2017; Satpute and Kumar 2020). India has already met its voluntary objective of decreasing the emissions intensity of its GDP by $21 \%$ over 2005 levels by 2020 , and the country has aimed to achieve a $35 \%$ reduction by 2030 (The Economic Times 2020), and wind has an important role to play in decarbonization. The status of the top five states in terms of installed wind capacity is discussed below.

\section{Tamil Nadu}

Tamil Nadu, which is just under 568 MW short of breaching the $10 \mathrm{GW}$ barrier for installed wind energy power, is well ahead of the rest of the country in terms of wind energy installation. The state jumped to the top of the list due to the rapid growth of technology and favorable policy regulations over the last decade, with approximately $2 \mathrm{GW}$

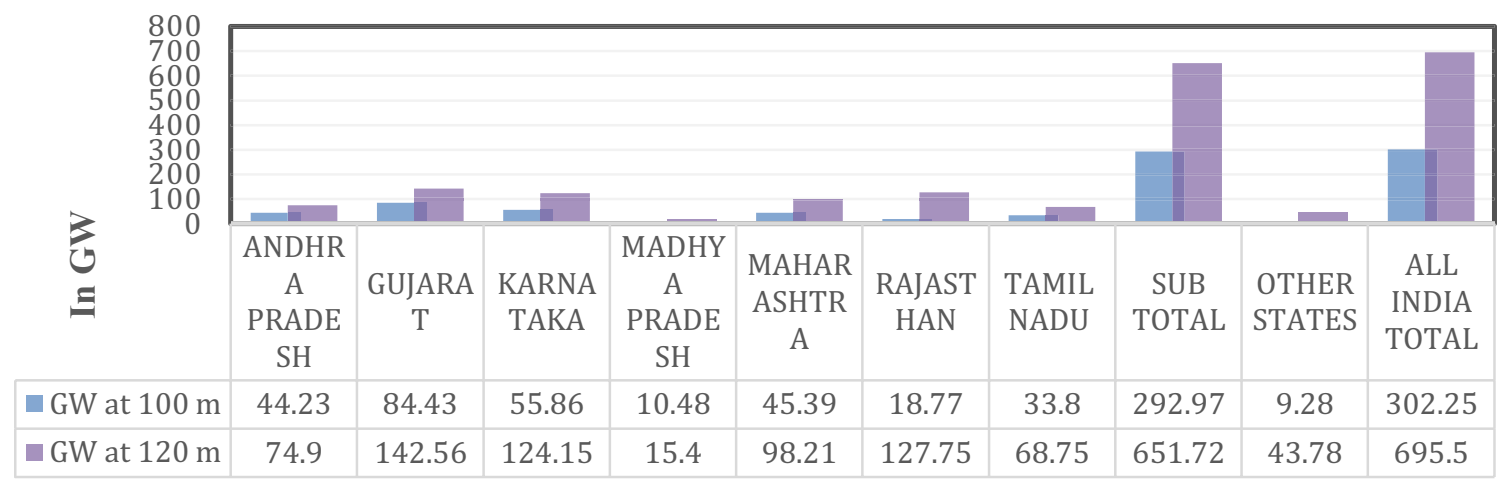

States

GW at $100 \mathrm{~m} \quad \mathrm{GW}$ at $120 \mathrm{~m}$

Fig. 1 Wind power potential in India Source: Standing committee on energy 2019-20 (MNRE 2020) 
Table 2 State-wise wind installed and generation capacity (MW)

\begin{tabular}{llllllllllll}
\hline STATE & $2010-11$ & $2011-12$ & $2012-13$ & $2013-14$ & $2014-15$ & $2015-16$ & $2016-17$ & $2017-18$ & $2018-19$ & $2019-20$ & $2020-21$ \\
\hline Tamil Nadu & 997.4 & 1083.5 & 174.6 & 107.38 & 124.45 & 158.8 & 247.57 & 335.64 & 723.82 & 335.44 & 303.7 \\
Karnataka & 254.1 & 206.7 & 201.7 & 183 & 230.5 & 230.9 & 882.3 & 857 & 86.5 & 95.7 & 148 \\
Maharashtra & 239.1 & 416.5 & 288.6 & 1074.5 & 273.45 & 207.85 & 117.55 & 12.6 & 10.2 & 206.2 & 0 \\
Rajasthan & 436.7 & 545.7 & 615.4 & 98.8 & 267.7 & 685.5 & 287.7 & 16 & 2 & 0 & 27.1 \\
Andhra Pradesh & 55.4 & 54.1 & 202.2 & 298.5 & 166.3 & 400.1 & 2187.45 & 348.1 & 123.5 & 2 & 4.2 \\
Madhya Pradesh & 46.5 & 100.5 & 9.6 & 37.4 & 143.9 & 1261.4 & 356.7 & 22.1 & 0 & 0 & 0 \\
Kerala & 7.4 & 0 & 0 & 0 & 0 & 8.4 & 8 & 1 & 0 & 10 & 0 \\
Gujarat & 312.8 & 789.9 & 208.3 & 279.8 & 126.9 & 392.4 & 1392 & 272.8 & 459.65 & 1468.45 & 1020.3 \\
Telangana & - & - & - & - & - & 77.7 & 23.1 & 0 & 27.3 & 0 & 0 \\
Others & 0 & 0 & 0 & 0 & 0 & 0 & 0 & 0 & 0 & 0 \\
TOTAL & 2349.2 & 3196.7 & 1700.4 & 2079.4 & 2333.2 & 3423.05 & 5502.37 & 1865.24 & 1480.97 & 2117.79 & 1503.3 \\
Cumulative Capacity & 14,156 & $17,352.7$ & $19,053.1$ & $21,132.5$ & $23,465.7$ & $26,777.39$ & $32,279.76$ & 34,145 & $35,527.43$ & $37,744.16$ & $39,247.46$ \\
Annual Generation & - & - & - & - & - & - & 1104.82 & 1263.98 & 1488.87 & 1551.51 & 1230.81 \\
Average CUF (\%) & - & - & - & - & - & - & 29.21 & 27.01 & 23.86 & 24.32 & 31.88 \\
\hline
\end{tabular}

Source: The Indian Wind Energy Association (INWEA)

more installed capacity than the second best state in the nation. When it comes to wind potential, the state is outmatched by five others, with $68.75 \mathrm{GW}$ (at $120 \mathrm{M}$ ). The state also has the country's largest onshore wind farm, the 1,500 MW Muppandal facility. It is in the Kanyakumari district and features many wind turbines ranging in size from $200 \mathrm{KW}$ to $1,650 \mathrm{KW}$.

Additionally, the state ranks second in renewable energy installations over the last two years, having installed 994.14 MW, 688.58 MW of which was the wind. The state has made significant advances in wind energy generation, with large-scale plant construction beginning in the early 1990s. However, this has also been the reason for the underutilization of wind resources as most of the wind energy plants have either completed or are nearing the end of their defined lifecycles. These wind turbines have lower capacities $(500 \mathrm{~kW})$ and lower hub heights (25-30 m), and owing to related technical problems and inefficiencies, these aging turbines typically result in poor Capacity Utilization Factors (CUFs).

\section{Gujrat}

Gujarat ranks second in terms of installed wind power, with $8.30 \mathrm{GW}$. Overall, the state is without a doubt the most resource-rich in terms of wind energy, ranking first in terms of wind energy capacity with $142.56 \mathrm{GW}$ (at $120 \mathrm{M}$ ). Additionally, the state ranks first in wind energy installations in FY 2020-21, with 1020 MW. The state has a dedicated wind and land policy which has remarkably impacted the growth, and it has been discussed in the later part of this paper.

\section{Maharashtra}

Maharashtra is third on the list, with $5 \mathrm{GW}$ of installed wind power. Moreover, the state has a wind potential of 98.213 GW (at $120 \mathrm{M}$ ), ranking fourth in terms of wind energy potential. The state is home to three prominent wind farms: the $528 \mathrm{MW}$ Brahmanvel wind farm in Dhule, the $278 \mathrm{MW}$ Dhalgaon wind farm in Sangli, and the 259 MW Vankusawade wind park in Satara.

\section{Karnataka}

Karnataka ranks fourth in terms of installed wind energy output, with $4.9 \mathrm{GW}$ installed. With a wind capacity of $124.155 \mathrm{GW}$ (at $120 \mathrm{~m}$ ), the state ranks third behind the two western states of Gujarat and Rajasthan. After a sudden transition in bidding scheme, the state new installations witnessed a falling trend, but the market is currently stabilizing, and numerous unique aspects of state RE policy are playing a significant role (discussed in detail in Table 4).

\section{Rajasthan}

Rajasthan ranks fifth on the ranking, with a steady wind power output over the last three years. The state's cumulative wind power installed capacity was $4.32 \mathrm{GW}$ at the end of February 2021. At $127.756 \mathrm{GW}$, the state has the second highest wind potential in the country after its neighbor Gujrat. However, by the end of March 2021, annual wind power generation had fallen by $7 \%$ compared to the previous year. Rajasthan is also home to the Jaisalmer Wind Park, 
India's second largest onshore wind farm, with a capacity of 1,064 MW.

The country has brought several policy changes in the last few years, and it has set high targets, but it has also been observed that new installations in the wind energy sector have declined by half in the last two years. There have been more than $17 \mathrm{GW}$ of capacity up for auction since 2017, though approximately one-third were unsubscribed or canceled even after allotment (GWEC 2020). However, the country is expected to build 11-17 GW of wind power between 2020 and 2022, bringing the total installed base of wind power in India to 54-55 GW by 2022 (GWEC 2020). The slowdown in wind power installations was further severely affected by the COVID-19 pandemic.

\section{Impact of COVID-19 on wind sector in India}

When the whole world was undergoing hardship due to COVID-19, how can a developing country like India be spared? From people losing jobs to industries being shut down for many months, every sector was affected in some way, or the other, the renewable energy sector was one of them. If we talk about wind energy specifically, the various project expansion took a setback in the wind sector for most of the year as there were transportation restrictions, supply chain issues, and shortages of workforce weighed down the sector due to COVID-19 (Fig. 2). While wind installations rose in the third quarter of 2020 (Q3 2020), which is still considerably lower than the same quarter from the previous year. In Q3,2020, about $295 \mathrm{MW}$ of wind projects was installed, a near of $117 \%$ progress from the earlier quarter's $136 \mathrm{MW}$, but a sharp $65 \%$ decline from the third quarter of 2019 (841.2 MW) of installations, according to the data released by CEA. The Q4 2020 data show a sign of recovery in wind power installations (500 MW).

The sector-specific policy is important for the growth and development of any industry. It has been observed that energy policies affect the renewable sector including wind power production. It may be argued that without a specific energy strategy, a nation would be unable to address pressing issues such as reducing carbon emissions, energy shortages, etc. Energy policy may include laws, tariffs, and investment incentives, the country's planned energy production, energy efficiency recommendations, policies to promote the energy sector, taxes, and other public policy initiatives. Some of the key policy measures are discussed below.

\section{Key policies and support programmes for wind power in India}

Following the two oil shocks of the 1970s, energy self-sufficiency was established as the main catalyst for renewable energy in the country. India was among the first countries to create a separate ministry for green energy. In March 1981, the Department of Science and Technology established the Commission for Additional Sources of Energy in response to the abrupt rise in the price of oil, the risks connected with its unanticipated supply, and the negative impact on the balance of payments situation. It began with the rising concern for the country's energy security; green energy has gained prominence in recent years. At the central stage, Fig. 3 depicts historical advances in renewable energy, especially wind energy. Policies and tariff controls have had a direct impact on the growth of the wind industry. Some of the most important policy measures about wind energy development have been discussed.

\section{Accelerated depreciation}

According to income tax law, companies engaged in renewable energy such as solar and wind were provided with accelerated depreciation (AD) on a written down value (WDV) basis at $100 \%$ in the 1990 s later revised to $80 \%$ in 2002 and 40\% in 2017 (NRDC and CEEW 2014; Das et al. 2021). The AD program can be termed as a

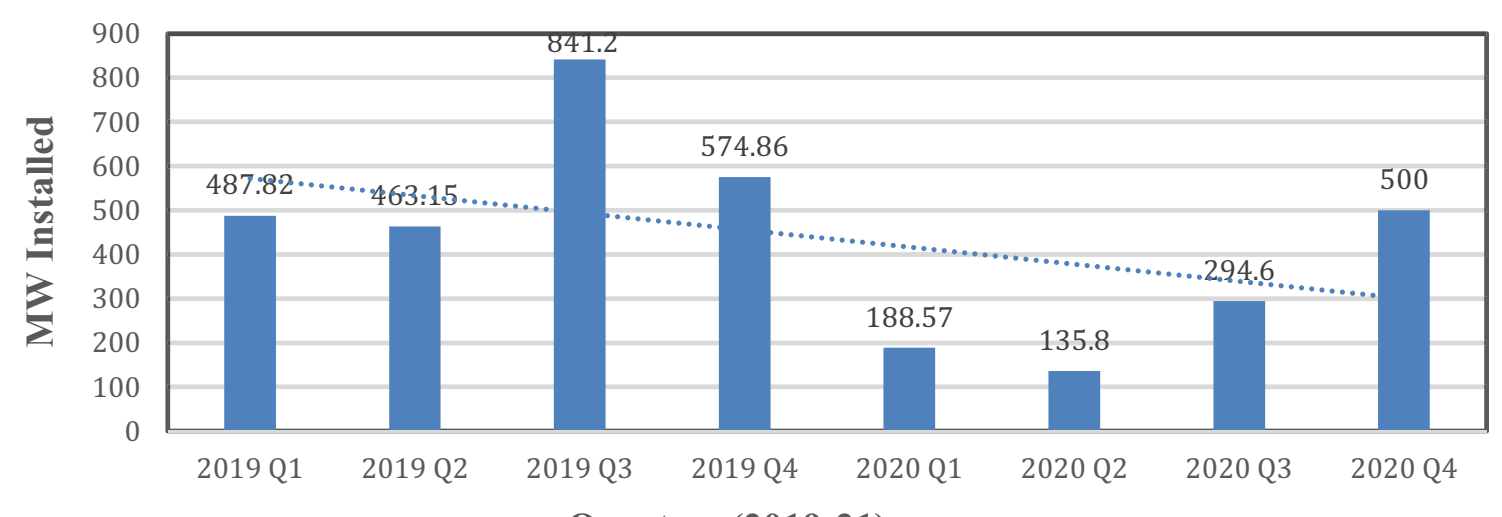

Quarters (2019-21)

Fig. 2 Wind power installations in India by quarters of 2019-2021 Source: Compiled by authors taking data from CEA (CEA) 
major incentive for new project developments (Kumar et al. 2019). It promoted the involvement of both large businesses, small investors, and captive consumers in the industry, contributing to the efficient deployment of wind power. A captive power plant is one that is built and operated by an industrial or commercial user for their energy use, and its users are referred to as captive consumers. For many factors, the GOI revoked the AD scheme in 2012, including the belief that the wind industry had achieved scale, and, in some instances, there have been cases of abuse of the AD system by developers to earn tax breaks with sub-optimally running wind farms. Subsequently, the production of wind power in 2012 and 2013 fell by $18 \%$ and $42 \%$, respectively, compared to 2011 (NRDC and CEEW 2014). Considering the significant reduction in wind power generation, the GOI announced plans for the revival of the AD program in July 2014. However, an entity can get the benefit of either accelerated depreciation or generation-based rewards (GBIs), but not both.

\section{Generation based incentive}

In December 2011, the GBI program was implemented. GBI's primary objectives include increasing the investor base, boosting real generation through a results-based reward, enabling the admission of independent wind power providers, and attracting foreign direct investment. Wind generators were to earn INR 0.50 / unit of power supplied to the grid for not less than four years and not more than ten years, with a capital of INR 10 million per MW, under the program. During the first four years, the total reimbursement in a year should not exceed one-fourth of the maximum incentive limit. GBI scheme was also discontinued in 2012 along with AD but it was reinforced in 2013.
Fig. 3 Historical development of wind power in India Source: Compiled by authors from different sources

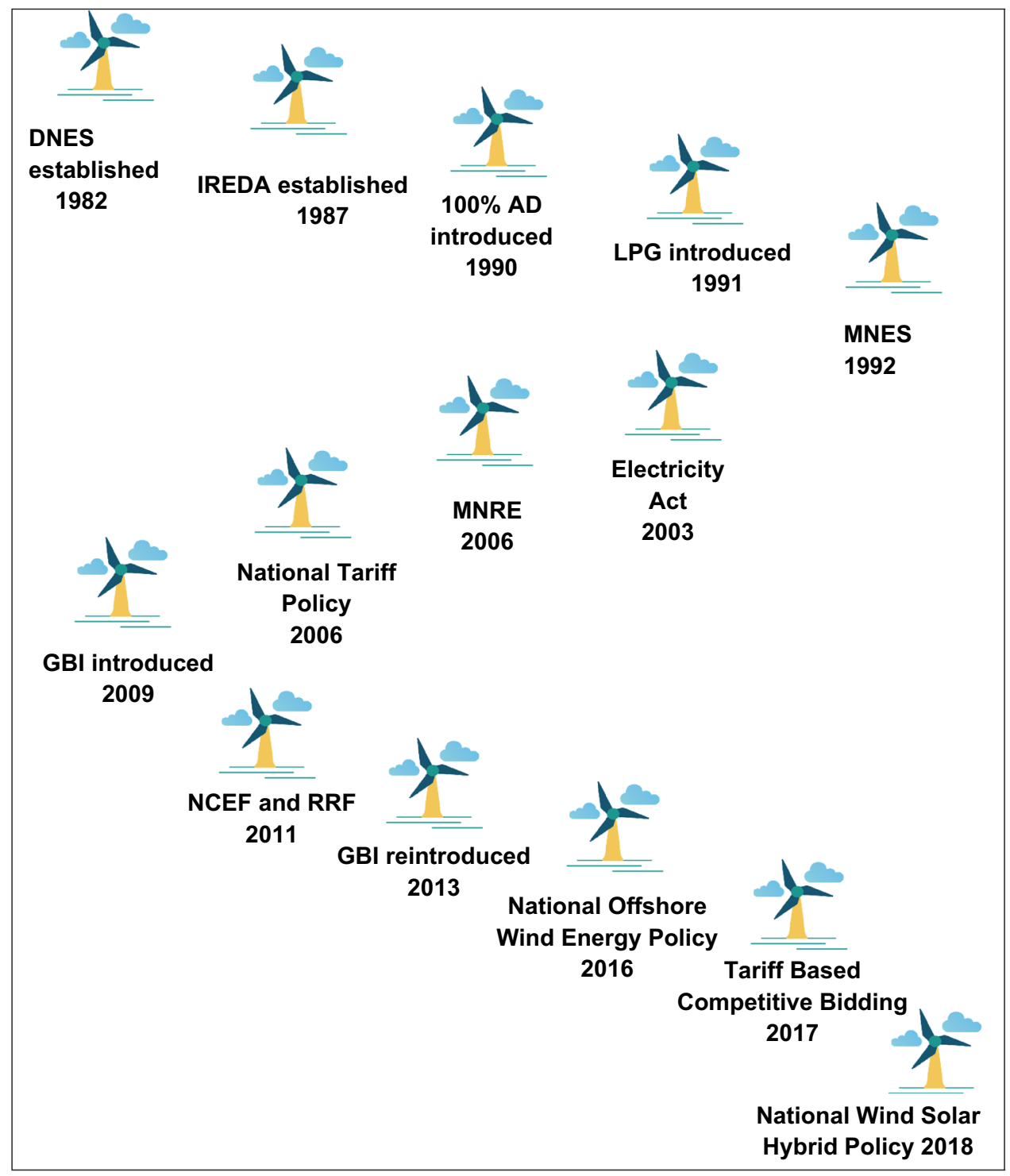




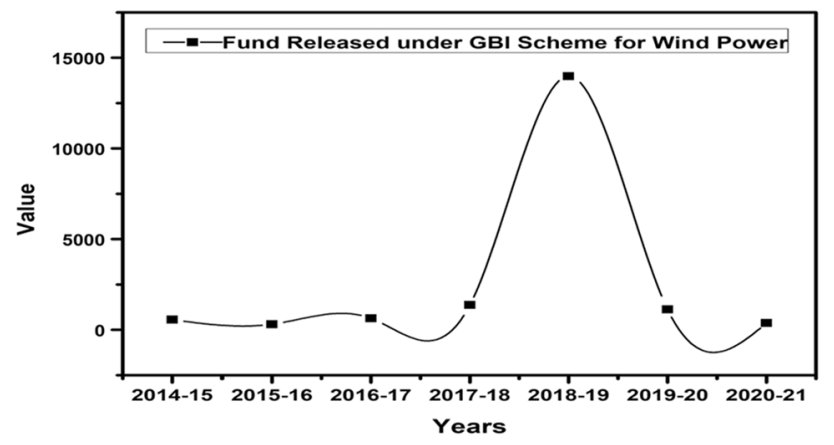

Fig. 4 Fund released under GBI scheme for wind power in India Source: Compiled by authors taking data from IREDA (IREDA 2020)

The progress and growth of wind power in India can be attributed to this scheme. Figure 4 shows the fund allocation under the GBI scheme for wind power development in India. GOI has allotted more than INR 180 billion from Fiscal year (FY) 2014-2015 to FY 2020-2021, the highest being in FY 2018-2019 (IREDA 2020).

\section{Private investment; renewable purchase obligation}

Private firms are present across the power value chain, including power generation, transmission, and distribution. Private sector enterprises, including foreign investors, have formed joint ventures to offer renewable energy and power to private or captive consumers. The Grid Interactive Renewable Power is dominated by the private sector but is substantially dependent on government policies at the same time. As of May 2020, the private sector accounted for $95.43 \%$ of the installed capacity in renewable energy (Law Business Research 2020). Different acts like the Electricity act 2003, National Electricity Policy, and Tariff Policy of 2016 have all played an essential part in the growth of renewable energy projects development. Section 86(1) (e) of the Electricity Act and National Tariff Policy enacted compulsory Renewable Purchase Obligations (RPOs) promoting states' wind, solar, and other clean energy sources.

RPOs require a proportion of all electricity from renewables and are met through direct purchases through bilateral contracts (Chawla et al. 2020). RPOs are classified as Solar and Non-Solar RPO. The Ministry of Petroleum in 2018 has notified the long-term growth trajectories of RPO's for solar and non-solar categories, uniformly for the whole country. The RPO's notification is $10.50 \%$ each for both solar and non-solar (MOP 2018a).

\section{Corporate renewable PPA}

Many companies are seeking forms of renewable energy to fulfill sustainability practices. While reducing power usage is the first step to lower energy costs and reduce emissions, services must remain operational as well. Renewable energy makes up for the remaining requirement in power. Corporate renewable PPAs ensure that corporations reduce their environmental footprint and energy costs. Corporate renewable PPA's are contracts between a corporate buyer and a developer which allow them to purchase renewable power at a pre-agreed price for a pre-agreed period. It has have become increasingly diverse and innovative and is now widespread worldwide. The WBCSD report 2021 indicates that more than $70 \mathrm{GW}$ of capacity has already been injected globally, compared to just $300 \mathrm{MW}$ in 2009 through corporate renewable PPA. India has also seen a dramatic increase in corporate renewable sourcing. According to Bloomberg New Energy Finance (BNEF), the Indian market accounted for $1.4 \mathrm{GW}$ of new corporate renewable power capacity in 2019 , which was $1.2 \mathrm{GW}$ in the previous year. However, in 2020, India's renewable PPAs slowed significantly $800 \mathrm{MW}$ as compared to $1.4 \mathrm{GW}$ in 2019 due to new restrictions at the state level in banking, reversing open access policies and the COVID-19 pandemic.

\section{Tariff policy}

The Central Electricity Regulatory Commission (CERC) has developed new tariff rules for renewable energy projects (CEA). These regulations went into effect on July 1, 2020, and will remain in effect until March 31, 2023. Wind schemes are subject to project-specific tariff regulations, rather than generic tariff regulations since the cost of project development varies from state to state. Wind power projects would have a useful life of 25 years. The CERC considered a debt-to-equity ratio of 70:30, with a return on equity of $14 \%$. For the first 15 years, a depreciation pace of $4.67 \%$ each year is introduced, and the remaining depreciation would be uniformly divided throughout the project's remaining productive life. The Commission has estimated that the capacity utilization factor (CUF) of $22 \%$ for annual mean wind power density up to $220 \mathrm{~W} / \mathrm{m} 2$, and $24 \%$ for annual mean wind power density between 220 and $275 \mathrm{~W} / \mathrm{m} 2$. Similarly, the CUF for the annual mean wind power density of $276-330 \mathrm{~W} / \mathrm{m} 2$ would be $28 \%$, and $33 \%$ for $331-440 \mathrm{~W} / \mathrm{m} 2$. CUF would be $35 \%$ for average mean wind power density greater than $440 \mathrm{~W} / \mathrm{m} 2$.

Formerly, under the revised Tariff Policy 2016, participants in a competitive bidding process have been exempted from inter-state transmission charges and losses for solar and wind power generators commissioned up to December 2019 for 25 years from the date of commissioning (MOP 2018b). It was also observed that tariff caps have been reasons to slow down auction activity in the market. Instead of a market-based auction in which the lowest bid wins, developers have refused to bid at the tariff levels specified by 


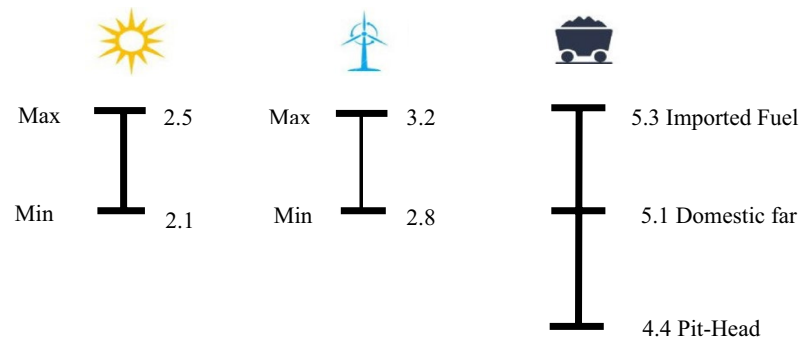

Fig. 5 LCOE comparison of different sources of energy, 2020 Source: GWEC Note: The term "Pit-Head" refers to coal plants that use domestic coal and are located close to the mine; "Domestic far" refers to coal plants that utilize domestic coal but are located more than $500 \mathrm{~km}$ from the mine. Imported coal-fired power facilities rely on imported Australian coal

state agencies. Many tender deadlines have been postponed or retendered because of the upper tariff limit. Considering this, MNRE has announced that forthcoming bids would no longer have upper ceiling tariffs or tariff limits (Jai 2020). The abolition of the tariff cap provides an opportunity for wind developers to bid higher and factor in implementation costs.

States also have their tariff policy, which establishes tariff rates on a year-to-year basis (Table 4) while considering market conditions, potential, and CERC guidelines. Before the implementation of the reverse bidding system, the feedin rate was about INR 5-6/unit. Tariff rates have decreased considerably since $2016-17$ because of low bidding by companies/developers, creating a sustainability issue in the long run. Telangana is an outlier in terms of its higher tariff rate than any other state. Despite the increased tariff, the state's new installations have decreased significantly in the previous 4-5 years, and it is negligible in FY 2019-2020 and FY 2020-2021 (Table 2). This might be because developers are not able to find customers at higher prices. The state should adjust its tariff policy in light of the present market scenario and implement a balanced approach to tariff determination.

In India, wind is a cost-competitive utility-scale resource. On average, wind $\mathrm{LCoE}$ is around $35 \%$ cheaper than the majority of coal facilities in the country (Fig. 5), delivering much-needed renewable energy. The cost difference between renewables and coal power plants is anticipated to widen further approaching 2025, as wind and solar costs would continue to decrease by $16 \%$ and $13 \%$, respectively (GWEC 2021b). For instance, the tariff rate in Gujrat for coal-based power plants ranges between INR 2.56-4.09/ kWh (GERC 2021a), whereas the tariff rate for Tamil Nadu-based Vallur thermal power plant is INR 3.60/unit (NTECL). This shows that wind power is way cheaper than fossil fuel-based power. The falling prices provide an opportunity with an economically viable phase-out strategy that would satisfy rising energy demand while saving money, creating employment, improving GDP, and achieving climate goals.

\section{National clean energy fund (NCEF)}

To provide funding for entrepreneurial projects and research in renewable energy technology, the Finance Bill 2010-11 created a separate National Clean Energy Fund (PIB 2011). Under NCEF, MNRE allocates funds to the Indian Renewable Energy Development Agency (IREDA) which distributes loans to renewable projects with the help of banks. The rate of interest in NCEF is currently at approximately $10-11 \%$, roughly 2-3\% less than the market interest rate. Developers can avail a maximum of up to $40 \%$ of project cost under this scheme. NCEF was being created by putting a cess of INR $50 /$ tonne of coal generation in 2010 which later increased to INR 200/tonne in 2015 and 400/tonne in 2016 (The Economic Times 2019). The total fund generated through coal cess amounts to be INR 864.4 billion, of which only INR 296.45 billion was transferred to NCEF. Of which actual disbursement was only INR 159.11 billion (The Hindu 2019). Following the implementation of the Goods and Services Tax (GST) in India, GOI started using the unallocated fund to compensate states for losses incurred as a result of the change in tax policy and to finance other projects such as the clean Ganga mission, which violates the fund's provisions. It is no longer limited to renewable energy research, but increasingly encompasses all aspects of environmental protection.

\section{Electricity (amendment) bill 2020}

The Ministry of Power released a draft proposal for Amendments to the Electricity Act 2003 in the form of the draft Electricity (Amendment) Bill 2020 (MOP 2020), with the overarching goals of maintaining customer centricity, boosting ease of doing business, and strengthening the power sector sustainability. The regulation proposes a National Renewable Energy Policy (NREP) to promote electric generation from renewable sources, and it proposes to set a minimum percentage to be sourced from renewable sources. The draft bill establishes harsher penalties for DISCOMs that fail to comply with RPO targets. The amendment requires the State Electricity Regulatory Commission (SERC) to adhere to the National Tariff Policy to reduce the Cross-Subsidy Surcharge (CSS) which may result in a strengthening of the open-access framework (PIB 2020b). There had been problems with the commissions' efforts to adopt the tariffs determined, resulting in cost escalation. To fix this issue, the amendment proposes a 60-day deadline for the adoption of the determined tariffs. In case of non-compliance, the tariff will be considered approved. The proposed bill also addresses payment security; it is proposed to empower Load 
Dispatch Centers to oversee the implementation of adequate payment security measures prior to contract-based electricity dispatch. The proposed amendments raise several concerns which need to be considered before the enactment of the bill. SERC's authority over cross-subsidy decisions in states has also been restricted, as National Electricity Tariff Policy (NETP) will specify the specific trajectory for crosssubsidy per year. Furthermore, while discussing how to pass on the advantages of subsidies, the amendment also cites the need to reduce cross-subsidization. The subsidy recovery deficit will have to be balanced by an increase in government expenses; hence, an increase in other tariff categories, such as electricity duty, will be needed. This suggests that cross-subsidization will continue in other ways, and the goal of reducing it will not be met. As a result, when settling on cross-subsidies, SERC should be consulted.

In terms of power procurement commitments, the NREP must include state regulator feedback for the respective RPO goals. Given that states were previously controlling RPOs, it would be wise to consider their perspectives on the matter. Besides that, the penalty for non-compliance with RPOs should be determined after comprehensive consultations with power sector stakeholders, especially DISCOMs.

\section{Repowering policy 2016}

To breathe fresh life into India's wind power sector, GOI announced a repowering policy in 2016 . The policy initially chose wind turbine generators with a capacity of $1 \mathrm{MW}$ for repowering. As part of the repowering strategy, IREDA will give an extra $0.25 \%$ interest rate rebate on top of the interest rate rebates provided to new wind projects funded by IREDA. Furthermore, all current fiscal and financial incentives offered to new wind projects will be available to the repowering projects. However, the market has not responded as expected; according to a right to information (RTI) request, not even a single project has taken advantage of an extra interest rate discount for wind repowering under the program between 2016 and 2020 (Khaitan and Co 2021).

Sites with high wind power density and speeds are scarce; the majority are situated in the states of Tamil Nadu and Gujarat. These sites are national assets, especially given India's aim to generate $140 \mathrm{GW}$ of wind generating capacity by 2030 . There are several wind farms in India that have outlived their projected life span of 20 years and continue to operate because they are financially profitable to their owners. According to the India Wind Power report 2014, more than $1 \mathrm{GW}$ of installed capacity with turbine sizes smaller than $1 \mathrm{MW}$ has reached the end of its designed life after 20 years (Table 3 ). It is important to note that these older wind turbines are located in some of India's greatest wind availability locations. However, they have comparatively low capacity utilization of $10-15 \%$, compared to more than $30 \%$
Table 3 State-wise and turbine size-wise wind Power Installation (before March 31, 2000)

\begin{tabular}{lclc}
\hline States & $<=0.5 \mathrm{MW}$ & $0.5-1.0 \mathrm{MW}$ & Total \\
\hline Tamil Nadu & 717.05 & 37.9 & 754.95 \\
Gujarat & 143.75 & 1.6 & 145.35 \\
Andhra Pradesh & 84.39 & & 84.39 \\
Maharashtra & 63.72 & 2.25 & 65.97 \\
Karnataka & 24.53 & & 24.53 \\
Madhya Pradesh & 21.1 & & 21.1 \\
Rajasthan & 2.9 & & 2.9 \\
Total Installed Capacity & $\mathbf{1 0 5 7 . 4 3}$ & $\mathbf{4 1 . 7 5}$ & $\mathbf{1 0 9 9 . 1 8}$ \\
\hline
\end{tabular}

capacity utilization of modern wind turbines. If the turbines are repowered, the project capacity may be increased by $2-3$ times, resulting in a significant increase in annual energy output.

\section{Green energy corridor}

The Green Energy Corridor Project's objective is to synchronize electricity generated by renewable sources such as solar and wind with electricity generated by conventional power plants on the grid. The Ministry sanctioned the Intra State Transmission System (InSTS) project in 2015-2016 to facilitate the evacuation of large-scale renewable energy. It is being implemented by eight states that are abundant in renewable energy sources: Gujarat, Karnataka, Tamil Nadu, Rajasthan, Andhra Pradesh, Madhya Pradesh, Maharashtra, and Himachal Pradesh. By March 2020, the project aimed to construct about $9400 \mathrm{ckm}$ of transmission lines and substations with a combined capacity of 19,000 megavoltamperes (MVA). However, only 6,258 ckm have been built as of September 2021 (MNRE). The objective is to evacuate 20,000 megawatts of large-scale renewable energy while also improving the system in the adopting states. The overall cost of the project is INR 10,141 crores. The funding structure comprises a $40 \%$ grant from the GOI, $20 \%$ state equity, and $40 \%$ loan from Germany.

It is expected that Green Energy Corridor would help renewable sector development by providing access to transmission lines. However, at few places like the Philippines and US state, Texas, Competitive Renewable Energy Zones (CREZs) have been created to provide guaranteed access to transmission lines which is termed as one of the biggest hurdles in renewable energy development. Texas created CREZs in 2005 around the state to designate new transmission lines to service these zones in order to break the deadlock between transmission and wind energy growth (Lasher 2008). By legislation, transmission projects have to be constructed prior to developing wind resources in the designated zones. The CREZ process entails identifying areas with the greatest 
potential for low-cost development; identifying priority or avoidance areas; conducting technical feasibility analyses; excluding areas that are not suitable for development; conducting economic analyses; selecting areas with the greatest probability of commercial development; bundling candidate zones and developing transmission enhancement options; conducting cost-benefit analyses, and developing the final transmission plan.

\section{Renewable energy certificate scheme}

Renewable Energy Certificates (RECs) are a market-based instrument designed to encourage renewable energy sources and the growth of the electricity market. A REC is issued when one Mwh of electricity is generated from a renewable energy source. Since its inception in 2010, the REC market has generated net sales of INR 92.66 billion (The Economic Times 2021). GOI is working on bringing some changes in the REC scheme to make it more useful for the renewable sector, it may include the abolition of the validity period which would make it perpetual. It would provide a safety feature, i.e., guarantee to the renewable industry about the purchase of power.

\section{State-specific policies for wind energy in India}

Grants and subsidies for renewable energy projects are also available at the state level. Many states have framed a renewable energy policy that gives preference to a particular energy source. State governments offer different tax and non-tax benefits, such as exemption from wheeling and transmission charges, RPO benefits, and other factors like third party sale and setting up of wind power projects for captive use (Table 4). Gujarat remains India's favorite location for implementing wind power projects even after having the lowest RPO obligation in comparison with other states. Several factors may account for the state's strong success in new project growth. The Gujrat government approached land allotment, which is often a stumbling block in project growth, with tact. Previously, the land was only allotted to state-tendered schemes, but after the 2019 land reforms, the process became simpler, which reflects in the development of the state's wind power. Karnataka also has a one-of-a-kind provision for addressing land allotment problems. There, the government has established a land bank to keep track of ready-to-use land for renewable projects. The state also has a special fund for clean energy ventures, known as the 'Akshaya Shakti Nidhi.' Rajasthan Wind \& Hybrid Energy Policy 2019 allows the allotment of government land for wind-solar hybrid power projects as well, but the absence of a suitable dispute resolution process has resulted in many lawsuits, causing project delays (Livemint 2021). State policies are also changing; now, states such as Maharashtra, Andhra Pradesh, and Rajasthan are focusing on the installation of hybrid plants to ensure an uninterrupted supply of electricity. Rajasthan's policy involves a one-of-a-kind element that aims to promote not only wind but also electric vehicles $(\mathrm{EV})$ in the state. If a wind project is built up to provide power to an EV station, a full exemption is granted on wheeling charges.

However, given the rising generation from renewable sources and the improvement of technology, there appears to be a shift in the trend, as it is now felt that renewable energy projects should be held to the same standards as traditional energy sources. Wheeling costs, which were formerly exempted in most states, are now levied by numerous states, including Gujarat, Maharashtra, Andhra Pradesh, and Kerala (Table 4). However, some states are encouraging captive projects and offering incentives for them. Wheeling charges are the fees paid for the transfer of electricity from the generating facility to the local substation. RPO has always played a key role in the development of renewable energy projects, and successive governments have emphasized enforcing it. Despite having the lowest RPO percentage in Gujarat, it has outpaced other states in terms of the current growth rate in the previous few years, as discussed earlier in Table 2. Moving away from a concessions-based system for new developments will aid in the development of a robust wind power market. However, moving away from concessions should, of course, apply only to new projects and not to those that have already commenced under a specific concessions regime. Such messages are necessary for robust wind energy project development. 


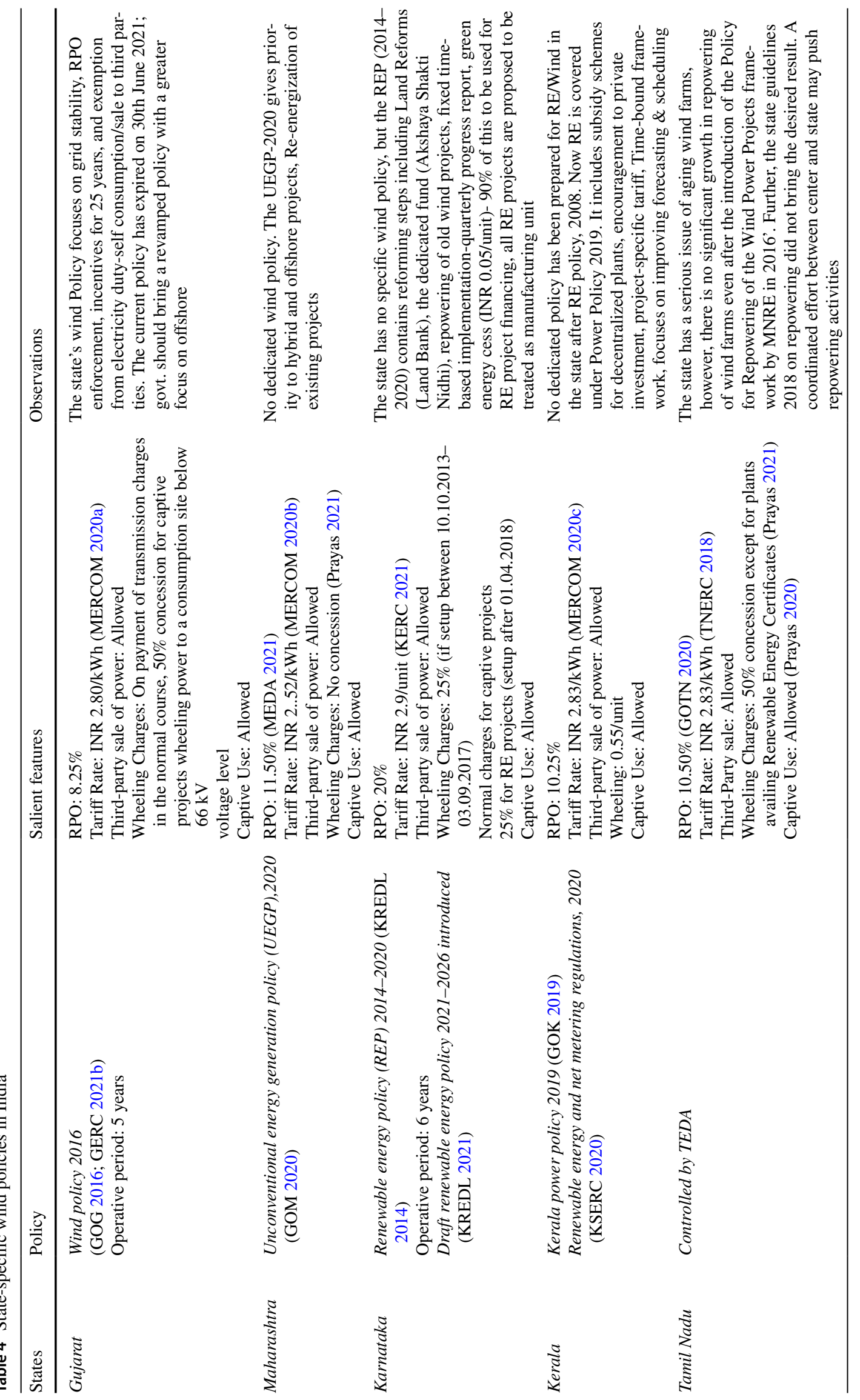




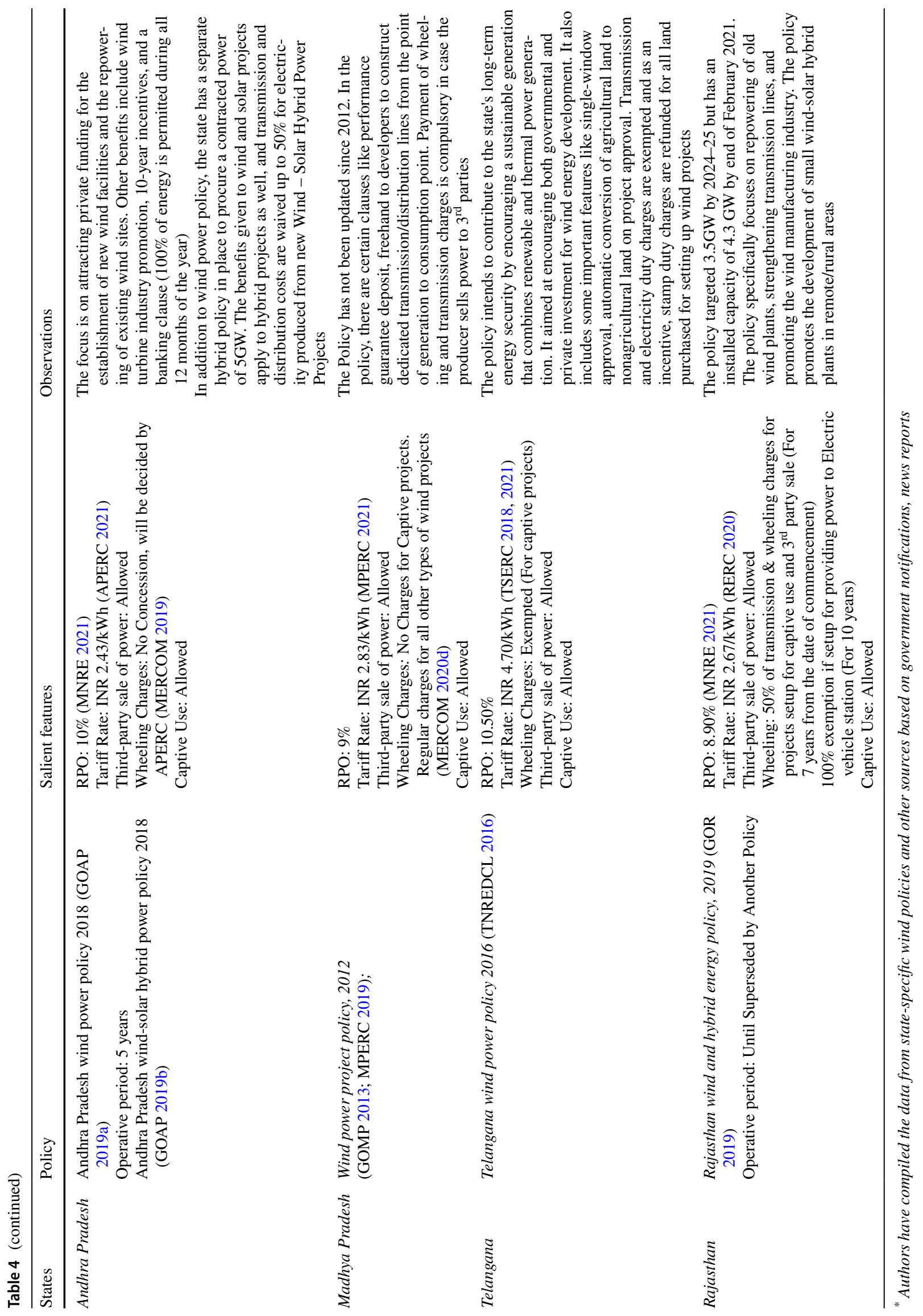




\section{Barriers to wind energy growth in India}

Several assessments recognize that problems like land acquisition, DISCOMS payment delays, and the bidding procedure are viewed as impediments to the expansion of wind power in India. According to the data, the country had significant development in the wind energy sector. However, due to several roadblocks, growth has been slower than anticipated. Some of the obstacles are explored further below.

\section{Land acquisition}

One of the most significant hurdles to wind project construction is land acquisition. Because the land is a state issue, numerous state government entities, including the revenue department and panchayats, among others, are involved in land procurement/lease clearances. The presence of many departments and entities makes the whole procedure very time-consuming and incredibly cumbersome. In general, it takes about 6-9 months to acquire land for new wind projects, but this duration sometimes extends to 18-24 months in some states. Project commissioning is required to be done in 12-18 months approximately in most of the central and state tenders, but approvals and procurement cover only take $60-70 \%$ of the time. However, the implementation of a single-window clearance system has significantly enhanced the process of granting land acquisition approvals, there are still many issues that result in project delays. The overall land footprint required to fulfill India's 2022 renewables target ranges from 55,000 to $125,000 \mathrm{~km}$, about the size of a state like Himachal Pradesh (Kiesecker et al. 2019). Despite huge land requirements only four states, Rajasthan, Madhya Pradesh, Maharashtra, and Gujarat, have framed dedicated government land allocation policies for renewable projects. Karnataka and Jammu \& Kashmir (J\&K) are yet to introduce standardized land-allocation policies. $\mathrm{J} \& \mathrm{~K}$, Leh, and Ladakh have recently been granted status as union territories ruled by the central government. Therefore, the government should capitalize on the huge potential for renewable energy in these regions through a structured land allocation policy to exploit the abundant land availability in these regions.

Many state governments permit the use and purchasing of agricultural land for renewable projects by converting agricultural land to the nonagricultural (NA) category. Presently, Rajasthan, Punjab, and Madhya Pradesh permit land use to be converted to a nonagricultural category without any fee being paid, whereas for these conversions, the states of Andhra Pradesh and Telangana take charges. Some states like Punjab, Uttar Pradesh, and Haryana offer $100 \%$ exemption for RE projects from stamp duty for land registration, whereas Madhya Pradesh offers a 50\% exemption. The majority of other states do not yet have such an exemption clause. States should work on digitizing the land records to reduce the ownership issues. A separate land utilization policy can be designed to map existing use vs intended use on pre-determined parameters.

\section{Payment delays by DISCOMS}

The distribution companies found it difficult to repay the overdue because of their poor financial performance over the years. The sum owed to renewable generators, at the end of January 2021, was more than INR 120 billion. A large part of this overdue debt is concentrated in a few states. The five states Tamil Nadu (INR 37.33 billion), Andhra Pradesh (INR 30.97 billion), Telangana (INR 15.56 billion), Karnataka (INR 10.43 billion), and Madhya Pradesh (INR 8.54 billion) contributing together about $84 \%$ of the overdue amount (Fig. 6). The financial health of DISCOMs has deteriorated over the years largely due
Fig. 6 DISCOMs Dues to Renewable Generators Source: Compiled by authors taking data from Praapti (PRAAPTI 2021)

\section{DISCOMs Dues to Renewable Generator (In Billion)}

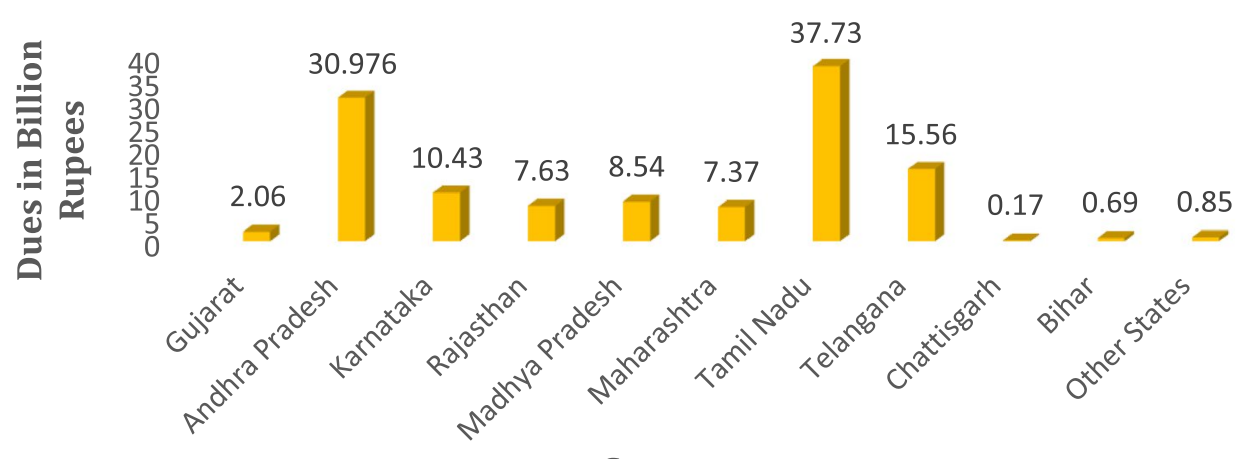

States

* Overdues represent payments that have crossed the due date and remain fully/partly unpaid. 
Fig. 7 Wind Auction Results (India), 2017-2020 Source: IEA (2022)
Indian Wind Auction Results, 2017-2020

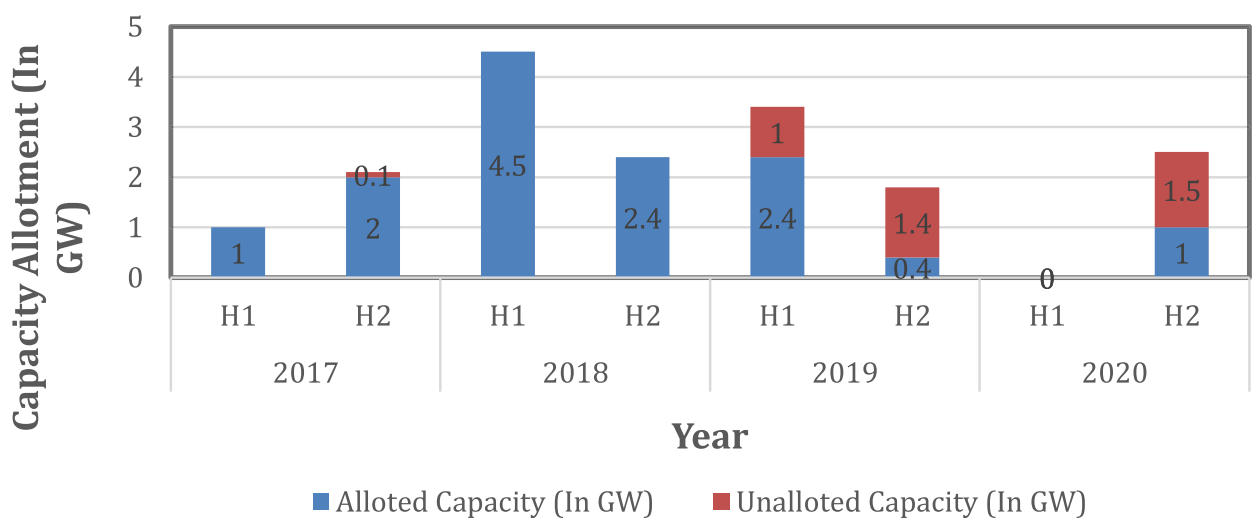

to high dues of over INR 500 billion to state-run departments. A long-term loan of INR 900 billion was extended in May 2020 to the states on stringent conditions that also include clearance of departmental dues to DISCOMs (Chatterjee 2020).

In the budget 2020-21, the Government again brought several provisions to improve the condition of the power sector which includes a package of INR 3.05 trillion for infrastructural development and financial improvements. The 'Late Payment Surcharge Rules, 2021' has also been introduced which apply to all the PPAs. The late payment fee will be calculated at the base rate of the late payment for the first month and the surcharge will increase by $0.5 \%$ every month of default but it should never be higher than $3 \%$ of the base rate (Ranjan 2021). Privatization of DISCOMs has also started in union territories and certain states. This strategy can facilitate a large amount of private sector participation in the distribution which may increase efficiency in the future.

\section{Bidding/Auction scheme}

From 2017 to 2018, auctions against tenders were almost fully awarded, and many a time oversubscribed by $30-35 \%$. However, activity has severely declined from the 2019 first half, with approximately $60-70 \%$ of volume remaining unallocated in auctions (Fig. 7). Since the implementation of the reverse auction mechanism in 2016, the development of wind projects has been severely hampered (Kandpal and Dhingra 2021). Just one wind auction took place during the first eight months of 2020, with only $40 \%$ of the announced $2.5 \mathrm{GW}$ successfully allocated (IEA 2020b). The primary cause for this is a decline in project developer interest in the industry. The benefits like AD and GBI were the key motivators for project developers until 2016-2017. At the time, the feed-in tariff was INR 5-6 per unit (Jhawar 2020). The implementation of competitive bidding resulted in lower tariffs. The approach initially boosted the wind sector's vitality but the prices fell sharply, with the lowest being INR 2.43 in 2017 (Chawla et al. 2020). Worse, the government imposed an upper rate ceiling for wind tariffs. Interests began to wane quickly. The underlying economic factors such as revenue uncertainty, land acquisition issues, and tariff ceilings lead to additional risks in wind power projects. The elimination of tariff ceilings, which was announced in March 2020, could improve participation by allowing developers to fully account for perceived project risks in their bids. In addition, the recent implementation of hybrid auctions may increase competition and participation by allowing developers to spread project risks through multiple technologies.

\section{Competition with solar}

The wind power market has been impacted by the country's shifting focus to become a major solar energy power. The solar tariff has been gradually coming down, which means wind power gets much stiffer competition from solar in the long run. Wind's long-term prospects in comparison with solar will be dependent on support from the government.

Wind and solar are two distinct sources of power and they should be viewed differently. The government should contribute to the equitable development of both sources. Unlike solar, the cost of developing wind power varies by state. The government should come in to build schemes, gather data, and then conduct competitive bidding. The wind sector faces a greater chance of curtailment due to high uncertainty, placing them at a disadvantage in comparison to solar projects. On the opposite, the wind industry is often denied the funding that the solar sector receives. Land and power grid integration are two critical issues in new project development. For solar parks, it is taken care of by the government, but it is completely missing for wind parks, causing a major delay in new project growth. 


\section{Tax burden}

The sale of electricity is exempted under the GST. Wind energy companies, on the other hand, are entitled to pay the applicable GST on the purchase of goods or services necessary for the manufacture of a plant. Due to the fact that electricity is free from GST, wind power firms are ineligible to claim input tax credits on commodities purchased for plant setup. As a result, the business incurs an additional expense. Additionally, there is an $18 \%$ GST on all services procurements, which may include operations and maintenance services, as well as consulting contracts, which is a hardship on businesses (KPMG 2020).

\section{New developments in wind energy sector}

The MNRE released a thorough plan for the development of wind-solar hybrid parks. It stated that it has identified viable locations for wind-solar hybrid projects in different states with the assistance of the NIWE. The government is also working on harnessing offshore wind potential in India to realize its high target through renewables. These developments are addressed in more detail below.

\section{Offshore wind}

Onshore wind farms are the most popular type of wind farm in the world today, but there is growing interest in several countries to construct offshore wind farms (Zheng et al. 2016), India is also not an exception. Despite a successful onshore wind track record, the pace of capacity addition has declined in the last few years due to state issues related to land acquisitions. Therefore, there could also be a role for offshore wind to play now, keeping the potential for alleviating the problem of land acquisition. India is endowed on three sides with a coastline of around $7600 \mathrm{~km}$ surrounded by sea and has strong prospects of harnessing wind energy from offshore.

Since 2010, wind energy has witnessed continuous expansion worldwide, with the quantity of electricity generated by offshore wind growing by $27.5 \%$ each year (Fig. 8). The expansion of the offshore wind sector has been encouraged largely in European countries. Europe added 2.9 GW of offshore capacity during 2020 increasing the total installed offshore wind capacity to $25 \mathrm{GW}$ (WindEurope 2021). Despite the development, offshore wind presently supplies less than $1 \%$ of the world's power supply (Gourvenec 2020). The reason for this untapped potential is that $80 \%$ of the wind blows continuously further offshore in water deeper than $60 \mathrm{~m}$ where turbines implanted in the sea bottom are hard to install with high-quality resources accessible in most major markets. The average sea depth of offshore wind farms under development in 2020 was $36 \mathrm{~m}$ (WindEurope 2021). Offshore wind can generate more than 420,000 TWh per year worldwide (IEA 2019). Considering the potential and development possibilities several nations are working towards building floating offshore wind farms. Moving further offshore provides wider sea regions with more consistent wind conditions, lowers influence on other economic activity, and minimizes any aesthetic impact on the shoreline. But transmission costs are higher, and building and operation are both more expensive. Offshore wind structures are fixed in the deep seabed while floating wind turbines are not fixed but floating structures that are attached to the seabed using flexible chains or steel cables. These can be manufactured and installed on land which is then deployed to the offshore installation location. Floating offshore platforms can be manufactured and deployed in most maritime settings and they are more ecologically friendly
Fig. 8 Global wind capacity (Onshore vs Offshore) Source: IRENA

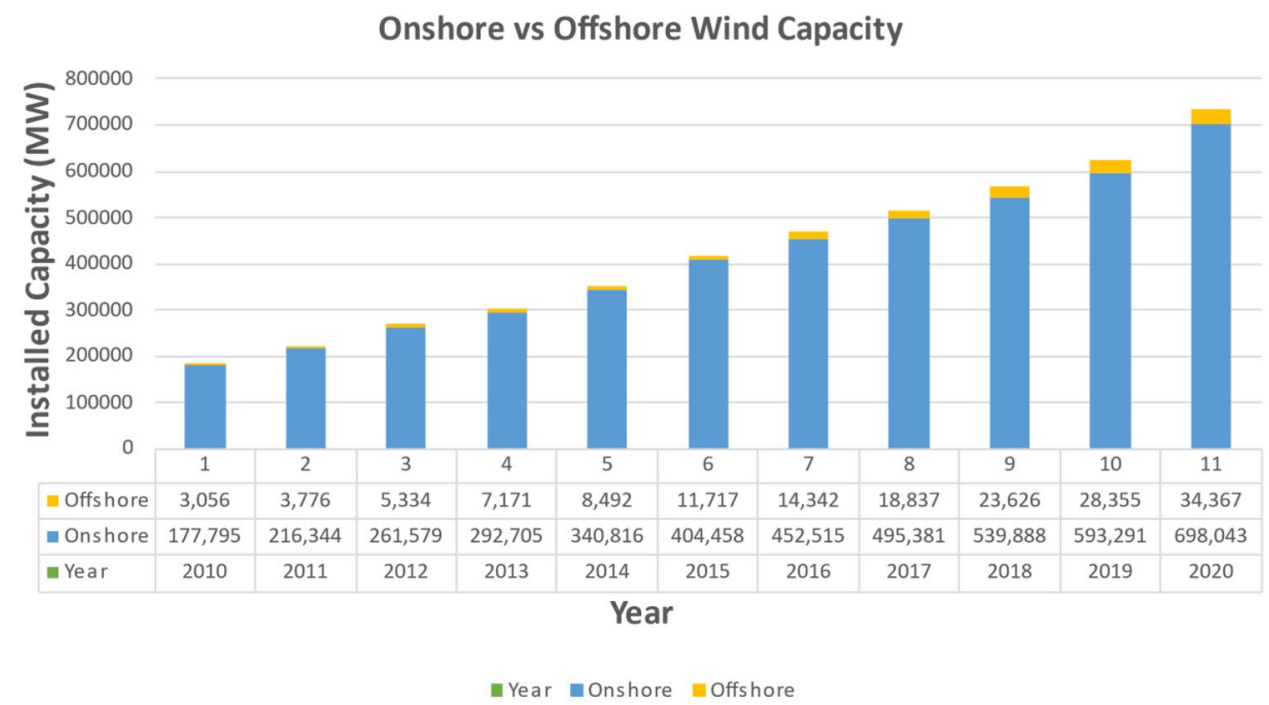


to sea life and have more output owing to increased wind speeds. The floating wind farms are technically feasible, they are not commercially viable. Doing anything offshore is costly. As per analysis for a commercial-scale floating offshore wind project in California offshore in 2019, the estimated LCOE ranges from \$83/megawatt-hour (MWh) to $\$ 180 / \mathrm{MWh}$ (Beiter et al. 2020), whereas the estimated average LCOE in European Union, China, USA is equal to $€ 164.6 / \mathrm{MWh}$, which is about $\$ 190.04 / \mathrm{MWh}$.

Offshore wind is in the initial stage of development in India. The government also introduced a National Offshore Wind Energy Policy in 2015 (The Economic Times 2015) and the area with nearly $71 \mathrm{GW}$ potential at $100 \mathrm{~m}$ height has been earmarked for offshore wind development (MNRE 2016) but the tender for the first $1 \mathrm{GW}$ offshore wind project in the Gulf of Khambhat has been delayed. Now, the focus has turned to the stronger wind resource area off Tamil $\mathrm{Nadu}$. India has announced a national target of generating 5 GW by 2022 and 30 GW by 2030 (IANS; Kumar J et al. 2020); however, the first plan seems to be no longer feasible and the second plan would require rapid deployment. The cost per MW offshore wind generation is comparatively higher than onshore because of developing structures in the marine environment. The desired tariff can be achieved with increased generation. The country can also consider floating offshore wind for achieving its goal of renewable targets but it requires huge investment and technological advancement. A feasibility study can be performed to check its prospects on the coasts of the Arabian sea as it is considered to be more stable than the Bay of Bengal.

\section{Wind-solar hybrid: India's next wave of renewable energy growth}

India's long coastline is blessed with high-speed winds and is filled with abundant solar energy, providing a bright future for the wind-solar hybrid (WSH) sector. More widespread use of WSH systems is occurring, as a result of higher wind and solar resource potential across numerous locations and better grid stability. WSH can be operated at the same or different locations based on the project demands. The hybridization of both technologies can result in several benefits like increased power generation efficiency as solar can generate power in the day, whereas wind is more productive at night. The Capacity Utilization Factor (CUF) of a hybrid plant is between 35 and $50 \%$ which is way better than wind or solar standalone (IEEFA 2020 ). The hybridization can also result in efficient utilization of transmission lines, higher grid stability. To promote and regularize the WSH sector, the government unveiled the National Wind-Solar Hybrid Policy in 2018. The policy includes special concessions and incentives for developers. Various state governments have also implemented their WSH strategies, such as Rajasthan and Gujarat.
11.6 GW of WSH capacity is anticipated to be installed over the next three years and compound annual growth (CAGR) is estimated to be 223\% from 2020-2023 (JMK Research 2020). According to statistics from the Solar Energy Corporation of India (SECI), around $12 \mathrm{GW}$ of capacity has been issued, and hybrid projects are receiving a positive response from developers, with tariff rates ranging from INR $2.4 / \mathrm{kwh}$ to INR3.2/kwh.

\section{India's target for 2030; Feasibility and necessary steps}

India's energy requirements are rapidly increasing, with growth in power demand and other energy uses. India has ambitious clean energy goals for 2030 to fulfill its climate targets and ensure energy security. At the 2015 UNFCCC conference of parties (COP) in Paris, India pledged 350 $\mathrm{GW}$ of electricity generation by renewable sources by 2030 , out of which $140 \mathrm{GW}$ is expected from wind power (Pratha 2021). It was later revised to $450 \mathrm{GW}$ by 2030 . For the 2022 renewable target, $34 \%$ contribution is expected from wind power. Considering the same percentage for the 2030 target, wind power contribution should be around $150 \mathrm{GW}$ by 2030 . India has taken great strides toward these goals. Renewable power stood at $94 \mathrm{GW}$ as of March 2021. This consists of $39 \mathrm{GW}$ of wind energy and $40 \mathrm{GW}$ of solar energy. The country has a long way to go. To meet the specified goals, it is required to add more than $350 \mathrm{GW}$ of renewable energy power over the next decade, which means an annual installation of $34 \mathrm{GW}$ in total and at least $16 \mathrm{GW}$ of wind power per year. However, on average only $2-3 \mathrm{GW}$ of wind power has been installed annually in the last few years. Along with the 2030 goal, the government has set a 2022 target of $175 \mathrm{GW}$. However, with just a year remaining, India seems likely to fall short of the mark: only about $53 \%$ of the target has been reached, and states that were supposed to be the main contributors are falling behind. The renewable sector especially wind necessarily require a coordinated policy initiative, including the following:

\section{Access to grid}

The expansion of transmission systems for renewable energy transmission is not keeping pace with the development of the renewable market, which is why land with plentiful wind resources is underutilized. Grid extension and enhancements are expected so that power grids can access high-quality wind resources, which are often located in remote areas away from conventional transmission networks. There is a need for a carefully designed set 
of laws, regulations, and procedures that could include the establishment of unique "Renewable Energy Zones" to promote investment in large-scale transmission extension and the deployment of cost-effective, grid-connected renewable energy. A long-term inter-state strategy must be established in collaboration with central and state bodies for transmission planning and growth. Government must encourage private players to accelerate private investment in transmission networks.

\section{Land availability}

The most pressing problem with wind energy projects is the difficulty of locating and acquiring appropriate land. In wind-rich states, most high wind capacity sites near developed transmission facilities have already been depleted. As discussed in the challenges section, many states lack a clear policy framework, so a clear land acquisition policy is the need of the hour. It would help in the timely development of wind projects.

\section{Separate wind RPO}

While the RPO goals are intended to raise demand for renewable energy and promote inter-state renewable power transfers, real compliance seems to be dismal. There is a need to provide an efficient enforcement process for staterun DISCOMs. Having a different wind RPO may also help non-wind-rich states maximize their procurement of wind energy.

\section{Grid integration guarantee}

The reduction in grid integration for renewable energy sources results in inadequate use of installed renewable energy resources and lower-than-expected returns for developers and investors. The Council on Energy, Environment, and Water has suggested a novel instrument known as the Grid Integration Guarantee (GIG) (Energy 2019). In case of curtailment, DISCOMs must pay the fixed portion of traditional power tariffs. Implementing risk-mitigation strategies such as the GIG will promote long-term development in the wind market.

\section{Location specific auctions}

Under competitive bidding, location-specific auctions are required for project development to ensure fair tariffs which must consider regional differences based on wind speed. Here, the government may acquire land and accelerate other regulatory permissions, as well as prepare ahead of time for transmission infrastructure.

\section{Funding India's renewable energy transition}

India's pledge to energy transformation necessitates substantial financial assistance. Although the renewable energy sector in India has attracted more than \$US42 billion in investment since 2014, the Institute for Energy Economics and Financial Analysis study reflects that reaching $450 \mathrm{GW}$ of power by 2030 would entail an additional US\$500 billion (Buckley and Trivedi 2021) and at least US\$ 199 billion for installation of the generation capacity alone (Singh et al. 2020). To overcome financial system constraints, the Union Budget 2021-22 suggested recapitalization of public sector banks and the establishment of a development finance institution (Dutt 2021).

MNRE received INR 57.5 billion in the Budget 2021-22, as well as INR 3 billion for the 'Green Energy Corridor' scheme. The government has also given an additional capital injection of INR 15 billion to IREDA. This is inadequate to meet the sector's needs, policymakers will have to consider focused interventions such as a limited-period subsidized credit enhancement and a green taxonomy, earlier proposed by the World Bank (World Bank group 2020) to substantially increase capital flows to renewable energy at an even lower annual rate.

\section{Recommendations}

At the moment, no benefits/concessions are available to wind energy developers. Certain actions, such as repowering old wind farms, offering generation-based incentives, tax concessions, reassessing the country's wind potential, and creating CREZs might assist in reviving wind energy. Repowering the older wind turbines of less than $1 \mathrm{MW}$ capacity with modern turbines of at least $2 \mathrm{MW}$ capacity could massively boost India's wind power generation. Repowering old turbines with new technology would result in higher capacity addition and generation from lesser turbines while utilizing existing grid infrastructure and land. However necessary policies are required to be introduced at the central and state level promptly. It may offer an extra boost to onshore wind additions and alleviate the negative impacts, i.e., less power generating capacity of first-generation wind turbine retirement. The Repowering policy of 2016 is not so effective. After 3 and 5 years of central repowering policy, Gujrat and Tamil Nadu have brought their state-specific wind repowering policy. The central and state governments should set a year-specific target for repowering of old sites. Other states should also bring their state-specific policies with focused incentives to encourage the site owners.

Other than increasing the installed capacity, it is equally important to focus on prioritizing generation. As discussed above, the GBI scheme was discontinued in 2012 
and it was again reimplemented in 2013. However, it was only applicable for the projects set up before 2017. GBI scheme highly supported wind generation. As can be seen from Table 1, there is a growth in the generation between 2017-2018 and 2018-2019, i.e., about 17\%, and the highest amount was disbursed in the year 2018-2019. However, its discontinuation for newer projects may adversely affect the wind power growth in India. The GOI should maintain a continuation in its policies for maintaining sustainable growth. On average only $2-3 \mathrm{GW}$ of power is being generated through wind annually. Generation-based incentives can surely result in an increased generation. Some tax concessions like exempting custom duty, reducing GST on operation and services under GST can also be offered for a fixed number of years. As mentioned earlier in the text that some independent studies claim the country's potential to be much higher than the current NIWE estimate, it is highly recommended that GOI performs a new study to asses India's wind power potential. Although green energy corridors are being developed to strengthen transmission lines, the government can think of creating CREZ like a module in high wind potential states like Gujrat, Tamil $\mathrm{Nadu}$, which would bring confidence in the industry as its basic feature includes providing a guarantee of access. Last but not the least, governments should be consistent in their reforms and policies and should be treated as par with solar energy. Along with the onshore wind, GOI should also prioritize offshore wind development to achieve its desired renewable targets. These changes would lead to expanding wind capacity by at least $4-5$ times.

\section{Conclusion}

The pattern of slow increase in the country's annual wind capacity additions demonstrates India's inability to monetize wind resources. Implementation of GBI, RPOs proved to be critical steps, resulting in a significant increment in wind power generation. However, the government's inconsistent policy support derailed the country's wind progress, further complicated by the COVID pandemic. Some states promote indigenous manufacturing, but there is no national policy. A national policy strategy aligned with 'Make in India' may be implemented to stimulate wind turbine and related accessory manufacture by offering incentives and subsidies, lowering the overall cost of wind project development. Competitive wind project bidding has slowed subscriptions in wind auctions. However, the bidding procedure was just recently implemented; its impact is expected to be good in the long run. Investors refrain from initiating new projects primarily due to dropping wind energy rates, guaranteed off-take, and discontinuation of certain financial support.
Despite substantial development in the wind power sector in the early years, market developments are slower than expected. The government must continue to take the required steps to solve the problems. To meet the aim, various areas must be addressed, including the streamlining of the land acquisition process, the strengthening of DISCOMs through capital infusion and efficiency enhancement by privatization, location-based auctions, and equitable policies on par with solar. Government can bring back its focus on wind or balance between the two. It is also necessary to repower aging wind turbines to boost efficiency, enhance transmission lines, and work on grid stability. The tremendous potential of offshore wind must be realized to meet the objective of $150 \mathrm{GW}$ by 2030 . To minimize disruptions, the federal and state government should work cohesively to achieve the national objective. Wind energy necessitates focused incentives at central and state levels. Further, the governments at various levels must ensure enabling environment to attract investment to boost wind power research and development, installation, and transmission.

Funding The authors did not receive support from any organization for the submitted work.

Data availability All datasets and software used for supporting the conclusions of this article are available from the public data repository.

\section{Declarations}

Conflicts of interest The authors have no conflicts of interest to declare that are relevant to the content of this article.

Ethics approval The manuscript has not been submitted to any other journal for simultaneous consideration. The authors declare that all ethical norms have been followed while preparing the manuscript.

Code availability Not applicable.

Consent to participate Not applicable

Consent for publication Not applicable

\section{References}

APERC (2021) Retail Supply Tariffs 2021-22

Bandyopadhyay S (2017) Renewable targets for India. Clean Technol Environ Policy 19:293-294. https://doi.org/10.1007/ s10098-017-1335-z

Beiter P, Musial W, Duffy P, et al (2020) The cost of floating offshore wind energy in California Between 2019 and 2032

Berkeley Lab (2012) Berkeley lab study shows significantly higher potential for wind energy in India than Previously Estimated

Boopathi K, Ramaswamy S, Kirubakaran V et al (2021) Economic investigation of repowering of the existing wind farms with 
hybrid wind and solar power plants: a case study. Int J Energy Environ Eng. https://doi.org/10.1007/s40095-021-00391-3

Buckley T, Trivedi S (2021) IEEFA: Global capital mobilising for India's $\$ 500$ bn renewable energy infrastructure opportunity. In: IEEFA.org. https://ieefa.org/ieefa-global-capital-mobil ising-for-indias-500bn-renewable-energy-infrastructure-oppor tunity/. Accessed 17 Jul 2021

Bórawski P, Bełdycka-Bórawska A, Jankowski KJ et al (2020) Development of wind energy market in the European Union. Renew Energy 161:691-700. https://doi.org/10.1016/j.renene.2020. 07.081

CEA (2021) All India installed capacity (in mw) of power stations (As on 31.03.2021)

CEA Central electricity regulatory commission New Delhi explanatory memorandum on draft central electricity regulatory commission (Terms and Conditions for Tariff determination from renewable energy

CSTEP;, WFMS;, SSEF (2015) Re-assessment of India's On-shore Wind Power Potential

Chatterjee A (2020) Power package: Rs 90,000-crore credit line to fund discoms afresh, but with strict riders

Chaturvedi KR, Sharma T (2020) Enhanced carbon capture and storage in depleted sandstone reservoirs using silica nanofluids. Mater Today Proc. https://doi.org/10.1016/j.matpr.2020.08.782

Chaurasiya PK, Warudkar V, Ahmed S (2019) Wind energy development and policy in India: a review. Energy Strateg Rev 24:342357. https://doi.org/10.1016/j.esr.2019.04.010

Chawla K, Aggarwal M, Dutt A (2020) Analysing the falling solar and wind tariffs: evidence from India. J Sustain Financ Invest 10:171-190. https://doi.org/10.1080/20430795.2019.1706313

Das A, Jani HK, Nagababu G, Kachhwaha SS (2021) Wind and solar power deployment in India: economic aspects and policy implications. African J Sci Technol Innov Dev 13:357-375. https:// doi.org/10.1080/20421338.2020.1762302

Dawn S, Tiwari PK, Goswami AK et al (2019) Wind power: Existing status, achievements and government's initiative towards renewable power dominating India. Energy Strateg Rev 23:178-199. https://doi.org/10.1016/j.esr.2019.01.002

Deep S, Sarkar A, Ghawat M, Rajak MK (2020) Estimation of the wind energy potential for coastal locations in India using the Weibull model. Renew Energy 161:319-339. https://doi.org/10.1016/j. renene.2020.07.054

Dutt A (2021) Funding India's clean energy transition. Bus, Line

Energy AR (2019) Grid Integration Guarantee

GERC (2021b) Tariff framework for procurment of power by distribution licensees and others from wind-solar

GERC (2021a) Determination of ARR and Tariff for FY 2021-22 Under GERC MYT Regulations 2016, and Section 62 of the Electricity Act , 2003

GOAP (2019a) Andhra Pradesh wind power policy - 2018

GOAP (2019b) Andhra Pradesh wind-solar hybrid power policy - 2018

GOG (2016) Gujrat wind-power-policy-2016

GOK (2019) Kerala power policy

GOM (2020) Unconventional energy generation policy - 2020

GOMP (2013) Wind power project policy

GOR (2019) Rajasthan wind and hybrid energy policy,2019

GOTN (2020) Tamil Nadu Governement Gazette

Gourvenec S (2020) This is how we can make floating wind farms the future of green electricity. In: World Econ. forum. https://www. weforum.org/agenda/2020/07/floating-wind-farms-green-energyelectricity-offshore/

GWEC (2021a) GWEC-Global-Wind-Report-2021

GWEC (2020) India Wind Outlook Towards 2022 Looking beyond headwinds

GWEC (2021b) Wind : The Critical Link to India's Clean Energy Transition
IANS Offshore wind will "surge" to over $234 \mathrm{GW}$ by 2030; India lags behind. In: 2020

IEA (2020b) Wind - Renewables 2020 - Analysis - IEA

IEA (2019) Offshore Wind Outlook 2019

IEA (2020a) Renewables - Global Energy Review 2020 - Analysis - IEA

IEA (2021) India Energy Outlook 2021

IEEFA (2020) Wind-Solar Hybrid: India's Next Wave of Renewable Energy Growth

IREDA (2020) Wind GBI / AD

Irfan M, Zhao ZY, Ahmad M, Mukeshimana MC (2019) Critical factors influencing wind power industry: a diamond model based study of India. Energy Rep 5:1222-1235. https://doi.org/10. 1016/j.egyr.2019.08.068

JMK Research Wind-Solar Hybrid: India's Next Wave of Renewable Energy Growth. In: 2020

Jai S (2020) MNRE removes cap on bids for renewables, industry says decision ill-timed. In: Bus. Stand. https://www.business-stand ard.com/article/economy-policy/mnre-removes-cap-on-bids-forrenewables-industry-says-decision-ill-timed-120030601421_1. html\#: :text=«Back-,MNRE removes cap on bids for,industry says decision ill-timed\&text $=$ There will be no tariff. Accessed 9 Jun 2021

Jhawar P (2020) Overshadowed: will wind power lose out to solar energy in India. https://www.downtoearth.org.in/news/energy/ overshadowed-will-wind-power-lose-out-to-solar-energy-inindia-68820. Accessed $11 \mathrm{Jul} 2021$

KERC (2021) Discussion Paper on determination of generic tariff for wind power projects $2021-22$

KPMG (2020) The Power of Nature

KREDL (2014) Karnataka Renewable Energy Policy 2014-2020

KREDL (2021) Draft Karnataka Renewable Energy Policy 2021-2026

KSERC (2020) Kerala state electricity regulatory commision

Kandpal D, Dhingra T (2021) Migrating to reverse Auction mechanisms in wind energy sector: status and challenges. Energy Policy 156:112352. https://doi.org/10.1016/j.enpol.2021.112352

Kaur P, Dhir A, Singh N et al (2020) An innovation resistance theory perspective on mobile payment solutions. J Retail Consum Serv 55:102059. https://doi.org/10.1016/j.jretconser.2020.102059

Khaitan \& Co (2021) The development of renewable energies in India Observatory 2021

Khan MF, Khan MR (2013) Wind power generation in india: evolution, trends and prospects. Int J Renew Energy Dev 2:175-186. https:// doi.org/10.14710/ijred.2.3.175-186

Kiesecker J, Baruch-Mordo S, Heiner M et al (2019) Renewable Energy and Land Use in India: a Vision to Facilitate Sustainable Development. Sustainability 12:1-14

Kumar CR, Kumar JV, D. Majid MA, (2019) Wind energy programme in India: emerging energy alternatives for sustainable growth. Energy Environ 30:1135-1189. https://doi.org/10.1177/09583 05X19841297

Kumar JCR, Vinod Kumar D, Baskar D et al (2020) Offshore wind energy status, challenges, opportunities, environmental impacts, occupational health, and safety management in India. Energy Environ. https://doi.org/10.1177/0958305X20946483

Lakhanpal S (2019) Contesting renewable energy in the global south: a case-study of local opposition to a wind power project in the Western Ghats of India. Environ Dev 30:51-60. https://doi.org/ 10.1016/j.envdev.2019.02.002

Lasher WP (2008) The development of competitive renewable energy zones in Texas. Transm Distrib Expo Conference 2008 IEEE PES Powering Towar Futur PIMS 2008 0-3. https://doi.org/10.1109/ TDC.2008.4517254

Law Business Research (2020) Renewable Energy 2021. https://www. khaitanco.com/sites/default/files/2021-01/2021_RenewableE nergy_India.pdf . Accessed 6 May 2021 
Livemint (2021) How solar farms fuel land conflict

MEDA (2021) Renewable purchase obligation-Maharshtra

MERCOM (2019) Andhra Pradesh Amends its Solar, Wind and Hybrid Policy - Pulls Back Incentives. https://mercomindia.com/andhrapradesh-solar-wind-hybrid-policy/. Accessed 11 Jul 2021

MERCOM (2020a) Gujarat Commission Approves Tariff of ₹2.80/kWh for Over $202 \mathrm{MW}$ of Wind Projects. https://mercomindia.com/ gujarat-commission-approves-tariff-wind-projects/

MERCOM (2020b) Maharashtra sets Tariffs to procure wind energy from projects with expired EPAs. https://mercomindia.com/ maharashtra-sets-tariffs-wind-energy/

MERCOM (2020c) Kerala Approves Tariff of ₹2.83/kWh to Procure $200 \mathrm{MW}$ of Wind Power from SECI. https://mercomindia.com/ kerala-approves-tariff-₹2-83-kwh-200-mw-wind-power-seci/. Accessed 18 Jul 2021

MERCOM (2020d) Madhya Pradesh: No Banking Facility for DISCOM Registered Captive Renewable Projects. https://merco mindia.com/madhya-pradesh-no-banking-facility-discom-regis tered-captive-renewable-projects/. Accessed 11 Jul 2021

MNRE Green Energy Corridors. https://mnre.gov.in/green-energycorridor

MNRE (2021) RPO Target

MOP (2018a) Long term growth trajectory of Renewable Purchase Obligationsfor Solar and non-solar for a period of three years i.e 2019-20 to 2021-22

MOP (2018b) Waiver of inter state transmission charges

MOP (2020) Amendment to Electricity act 2003

MPERC (2019) Madhya pradesh electricity regulatory commission

MPERC (2021) Aggregate Revenue Requirement and Retail Supply Tariff Order For Financial Year 2020-21

Ministry of new and renewable energy (2016) Standing committee on energy (2015-16). 20:1-85

NRDC, CEEW (2014) A Second Wind for India's Energy Market: Financing Mechanisms to Support India's National Wind Energy Mission. NRDC Int

NTECL NTECL Vallur Tariff Petition 2019-24.pdf

PIB (2011) Creation of National Clean Energy Fund

PIB (2020a) Contribution of Renewable Energy Sources is estimated to be around $21 \%$ of Electricity Demand in 2021-22 : R.K.Singh. In: Minist. New Renew. Energy. https://pib.gov.in/PressReles eDetailm.aspx?PRID=1602274. Accessed 6 May 2021

PIB (2020b) India prepares for a change in Electricity sector tPIB. (2020). India prepares for a change in Electricity sector through Proposed Electricity (Amendment) Bill 2020.hrough Proposed Electricity (Amendment) Bill 2020

Prakash O (2018) Wind energy potential, development and current trends in India: a review. Int J Ambient Energy 39:521-532. https://doi.org/10.1080/01430750.2017.1303636

Pratha J (2021) Wind-dominated renewables will be key to limit electricity sector emissions: Report. In: DownToEarth. https://www. downtoearth.org.in/blog/energy/wind-dominated-renewableswill-be-key-to-limit-electricity-sector-emissions-report-76226. Accessed 7 Jul 2021

Prayas (2020) TNERC's order on procedure for captive generation determination

Prayas (2021) Renewables, moving beyond concessions and waivers. https://www.prayaspune.org/peg/resources/power-perspectiveportal/253-renewables-moving-beyond-concessions-and-waive rs.html

REN (2021) GSR2021_Full_Report

RERC (2020) Rajasthan Electricity Regulatory Commission

Ramesh M, Saini RP (2020) Dispatch strategies based performance analysis of a hybrid renewable energy system for a remote rural area in India. J Clean Prod 259:120697. https://doi.org/10.1016/j. jclepro.2020.120697
Rani P, Mishra AR, Mardani A et al (2020) A novel approach to extended fuzzy TOPSIS based on new divergence measures for renewable energy sources selection. J Clean Prod. https://doi.org/ 10.1016/j.jclepro.2020.120352

Ranjan R (2021) Ministry of Power Issues New Rules for Late Payment Surcharge Payable by DISCOMs

Sadorsky P (2021) Wind energy for sustainable development: driving factors and future outlook. J Clean Prod 289:125779. https://doi. org/10.1016/j.jclepro.2020.125779

Satpute AV, Kumar EV (2020) Current scenario of wind power in India, government policies, initiatives, status and challenges. Int J Energy Sect Manag 15:209-226. https://doi.org/10.1108/ IJESM-03-2020-0007

Sharma S, Sinha S (2019) Indian wind energy \& its development-policies-barriers: An overview. Environ Sustain Indic 1-2:100003. https://doi.org/10.1016/j.indic.2019.100003

Singh R (2018) Energy sufficiency aspirations of India and the role of renewable resources: Scenarios for future. Renew Sustain Energy Rev 81:2783-2795. https://doi.org/10.1016/j.rser.2017.06.083

Singh VP, Dutt A, Sidhu G (2020) RE-Financing India's Energy Transition

TNERC (2018) Order on generic tariff for Solar power and related issues

TNREDCL (2016) Telangana wind power policy 2016

TSERC (2018) Telangana State Electricity Regulatory Commission Retail Supply Tariffs for FY 2018-19

TSERC (2021) Telangana State Electricity Regulatory Commission Tariff continuation order

Thapar S, Sharma S (2020) Factors impacting wind and solar power sectors in India: A survey-based analysis. Sustain Prod Consum 21:204-215. https://doi.org/10.1016/j.spc.2020.01.001

Thapar S, Sharma S, Verma A (2018) Key determinants of wind energy growth in India: analysis of policy and non-policy factors. Energy Policy 122:622-638. https://doi.org/10.1016/j.enpol.2018.08.004

The Economic Times (2020) India to achieve target of reducing 35 pc emissions intensity before 2030: Javadekar Read more at: https://economictimes.indiatimes.com/news/economy/policy/ india-to-achieve-target-of-reducing-35-pc-emissions-intensitybefore-2030-javadekar

The Economic Times (2021) Over Rs 9,000 crore worth of renewable energy certificates sold in India to date: Report. https://energy. economictimes.indiatimes.com/news/renewable/over-rs-9000crore-worth-of-renewable-energy-certificates-sold-in-india-todate-report $/ 82797570$

The Economic Times (2015) Union Cabinet approves National Offshore Wind Energy Policy - The Economic Times. https://econo mictimes.indiatimes.com/industry/energy/power/union-cabin et-approves-national-offshore-wind-energy-policy/articleshow/ 48884598.cms?from=mdr. Accessed 6 Jul 2021

The Hindu (2019) Panel pulls up govt. for diverting coal cess

The Economic Times (2019) Future of India's Green Fund From Coal

The World Bank (2019) Access to electricity (\% of population) World Bank, EG.ELC.ACCS.ZST

World Bank group (2020) Developing-a-National-Green-TaxonomyA-World-Bank-Guide

WindEurope (2021) Offshore wind in Europe - Key trends and statistics 2020

Zheng CW, Li CY, Pan J et al (2016) An overview of global ocean wind energy resource evaluations. Renew Sustain Energy Rev 53:1240-1251. https://doi.org/10.1016/j.rser.2015.09.063

Publisher's Note Springer Nature remains neutral with regard to jurisdictional claims in published maps and institutional affiliations. 


\section{Authors and Affiliations}

Abhishek Kumar ${ }^{1}$ (D) Divyanshi Pal ${ }^{1}$.

Sanjay Kumar Kar ${ }^{1}$. Saroj Kumar Mishra ${ }^{1} \cdot$ Rohit Bansal $^{1}$

$\triangle$ Abhishek Kumar

pm1901@ rgipt.ac.in

Divyanshi Pal

pm1904@ rgipt.ac.in
Sanjay Kumar Kar

skar@rgipt.ac.in

Saroj Kumar Mishra

skrmishra@rgipt.ac.in

Rohit Bansal

rbansal@ rgipt.ac.in

1 Department of Management Studies, Rajiv Gandhi

Institute of Petroleum Technology, Jais Amethi 229304,

Uttar Pradesh, India 